\title{
Stories of the holocaust: From the optics of Filipino learners
}

Escalante, Liza $\triangle$

Department of Education, Tagum City, Philippines (liza.escalante@deped.gov.ph)

Gomez, Dan

University of Mindanao,Tagum, Philippines (dangomez031986@gmail.com)

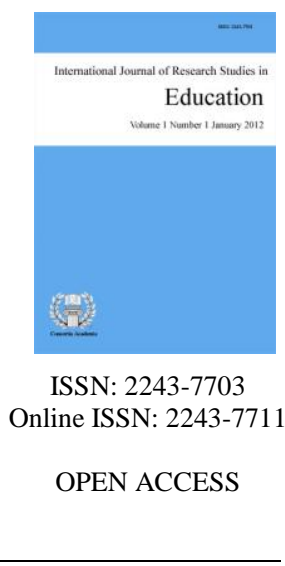

Received: 20 January 2022

\section{Abstract}

This study aimed to know the perspective on the stories of the holocaust and the lived experiences of twenty grade 11 senior high school students from secondary school in the division of Tagum City. This research employed qualitative employing phenomenological approach, which is deemed appropriate for this study since it sought to find out the lived perspectives of grade 11 students about the stories of the holocaust that they have read. Results of the study showed that students have diverse revealing perspectives about the stories of the holocaust, such as fear to fight, feeling of hatred to the oppressors, bravery leads to survival, admiration to survivors of the holocaust, condemnation of the oppressor's acts, and extending hands to the needy. These students needed guidance and support from their teachers in managing their emotions. They also needed support from the Department of Education to help them overcome the difficulties they encountered in the literature subject. Outcomes also confirmed that despite the different emotions that surfaced, most of the students still viewed the Holocaust as something that also had a positive impact despite the negative events that followed it.

Keywords: teaching English, holocaust, literary analysis, phenomenology, Philippines 


\section{Stories of the holocaust: From the optics of Filipino learners}

\section{Introduction}

Holocaust education brings vital views into the classroom as learners get a hold of the varied problems of racism, prejudice, and anti-Semitism, which are only a couple of topics in the literature concerning the holocaust. Some of the primary purposes of holocaust education are to instill awareness in citizens and to come up with an argument for the pertinence of holocaust education to enhance the development of well-rounded young learners. Apart from teacher engagement, students' outlook about the subject is considered most vital tin continuing the teaching and learning process in holocaust education (Cowan \& Maitles, 2017). It may be known to all nations of the world that six million Jews were killed during the Second World War, but this information is not something that most students know. Another piece of information that is not known to a lot of learners, including Filipino students, is that the Philippines opened its doors to Jewish refugees after the holocaust. This uncommon event in World War II history, simply tagged as "Rescue in the Philippines," was told in a 2012 documentary over social media. It was revived in November 2013 when Jewish and Israeli aid organizations worked to support hundreds of thousands of Filipinos ravaged by typhoon Haiyan (Pins, 2014).

To attain an understanding about the things that happened during the holocaust, students should be guided properly. It is vital to look not only at the acts of perpetrators but also at the experiences of victims, survivors, and those who helped the victims. According to Nobel Prize winner and Holocaust survivor Elie Wiesel, asking any survivor or his/her children will only provide information that someone who did not live through the event will never know or feel. This is because the survivors may not recall information because of a wall that cannot be pierced between the survivors' memories and their reflection. However, though it may seem impossible to ascertain the victims' experiences truly, and nothing may prepare people to experience the horror of this historical event, it is still significant to have a glimpse of the scope of this genocide and to have an appreciation of how humanity was stripped from millions of people (Morris, 2011).

The holocaust was given more recollection even in countries where the holocaust did not happen, because of extensive prewar Jewish populations and the immigration of the holocaust victims and perpetrators to some countries. Regions of the world that considerably accepted Jewish refugees tended to develop an interest in educating their citizens about the holocaust. In connection, the former Philippine President, Manuel L. Quezon, who was also the first President of the Commonwealth Government of the Philippines, in cooperation with Dwight Eisenhower, who later became the president of the United States, planned a way to get the Jews to reach the Philippines. The Frieds brothers and some people in the Jewish American Brotherhood assisted them in their plan. It was unfortunate that the Jewish refugees arrived in the Philippines during the Japanese invasion in 1938. Many Filipinos suffered and died, but the Jews, who were still traumatized by the traces of war, survived (Park, 2015).

Most Filipinos have not heard much about the Philippines' role in helping the Jews during World War 11. Although there was a documentary in 2012, it did not draw much audience until the showing of the film 'Quezon's Game.' The film centered around President Quezon's plan to shelter the Jews who were fleeing from Nazi Germany. Since the role of the Filipinos was a savior, this movie indeed made a difference as it has awakened pride and honor in every Filipino heart.

As a literature teacher at a senior high school in our school, I observed that students are not familiar with the stories of the holocaust, much less the rescue that happened in the Philippines. Learners of today are called millennials, but their technological exposure is not focused on history and human rights. They only heard one story about the stories of the holocaust, and that was the Diary of Anne Frank, as it was a part of their reading lessons during their junior high school English and literature classes.

While there has been some research to date about teachers' perceptions and preconceptions about the 
holocaust, we have not come across a study that utilizes a qualitative approach for that investigation that focuses on how the Filipino learners perceive this phenomenon, how they relate to the stories to the social issues at present, and what their insights are regarding what they have learned. This study will use relevant theories in the education community that will explain the importance of learners' appreciation of something as significant as the role of Filipinos in an important historical event such as the holocaust. This qualitative study will give us an insight into the students' insights after knowing that the Filipinos sheltered more than a thousand Jews. This act of kindness shown by our ancestors changed the way Filipinos look at the Jews and other European people. Withstanding the principles of human rights as the theory that was violated by the oppressive acts of the Nazis, identifying the gaps in this research is vital. This study will provide students with critical concepts that will help them better understand the role of Filipinos in a significant historical event such as the holocaust. This study would also shed light on the revealing perspectives of Filipino learners on stories of the holocaust.

The conduct of the study is deemed necessary since there is a need to pass this vital information to the students who might not have even the slightest idea of this significant event in history. Thus, it is important to address immediate issues related to the revealing perspectives of Filipino learners on stories of the holocaust. This study will hopefully give information to literature teachers about the significance of deepening the understanding of students in connection to what happened during the holocaust, which they can use as they inspire more teachers to take on this important educational task. Further, this research explores how the students relate the stories of the holocaust to the social issues at present and discovers the students' revealing perspectives and insights about these stories.

\subsection{The Purpose of the Study}

The purpose of this qualitative study on the holocaust is to reveal the perspectives of Filipino learners on Holocaust stories, relate the stories to current social issues, and gauge the readers' insight after reading the stories. Further, this is to link the students with world history and connect the social conditions like human rights, racism, and equality to the present. This study tried to get the students' perception while reading or watching the stories and documentaries of the holocaust. The researcher intends to gain a clearer understanding of the Filipinos' perception of equality, oppression, racism, war and conflict and the human rights condition of some countries in the world that were directly involved in the holocaust.

\subsection{Research Questions}

This study sought to answer the following questions:

$>\quad$ What are the revealing perspectives of Filipino learners on the stories? of the holocaust?

How do learners relate the stories to the social issues of the present?

$>\quad$ What are the insights from the stories that the readers learned?

\subsection{Theoretical Lens}

This study is based on the United Nations preamble, stating that we single-mindedly desire to save the next generation from the curse of war. As members of the United Nations, we firmly believe in the Declaration of Universal Human Rights, reaffirming the worth and dignity of every human being and upholding equality for all citizens of the world, whatever their race, religion, and citizenship. Moreover, Gatens and Johnson (2011) revealed in their study of the holocaust that the world needs a substantial, learned, and dynamic group of citizens whose knowledge is sufficient in the use of the framework of national and international law to prevent and stop genocide.

The idea of equality as part of the exercise of human rights is supported by socialism, which aims to end monopolies and social injustices in society. It also seeks the well-being of its citizens and advocates for social 
justice and rapid economic growth. The essence of socialism is fellowship and denies classes or standing in the society. Social justice observes impartiality. It also adheres in developing a person's totality by providing ownership to all and equal opportunity to become productive (Bradley Jr., 2018).

Finally, John Rawls created philosophies of justice in designating fundamental rights and duties and in defining the classification of social benefits of citizens in a society. This process was done through his social justice theory, integrating with social contract theory in creating these principles. To achieve fairness and equality, he argued that these two governing philosophies could be applied. The first is that every individual must have an equal and identical right as others, and second is that social and economic irregularities should be fixed to make them advantageous to everyone and be attached to offices for all (Miller, 1974).

\subsection{Significance of the Study}

The outcomes of this investigation will be substantial in the perception of literature as viewed by different kinds of people. The study will also help students in senior high school gain some insights on the issues relative to human rights, equality, and freedom and maybe a subject for literary analysis or a medium to study the situation of the community and the school as well. This study can also serve as a wake-up call for all citizens of any country to examine their political situation and whether their leaders are truly interested in public service and are open to every citizen of the world in need, or if they are only interested in personal gain. Lastly, this study would help future researchers, students, or even those in graduate school who have plans to research about the holocaust that involves the responses of the younger age group. The results of this study will help future researchers choose the suitable literature should they opt to advance their research.

\section{Review of related literature}

\subsection{Human Rights and Equality}

The philosophical literature on human rights is crammed with a confusing variety of definitions of human rights, ranging from the very detailed formulation by James Michel (2014) to the far shorter definitions offered by others such as Jack Donneley (2013) and James Griffin (2008). Philosophers disagree on what should be considered a right of a human being. The practical application of human rights is compromised by harmful indeterminacy. Thus, human rights are mainly based upon those rights specified within the principal UN Human Rights covenant and treaties. (Fagan, 2017). Also, through citizen engagement with global affairs, people fostered a collaborative response to predicaments related to compassion and morality. Thus, the possibility of solidarity where borders do not matter, and the protection of human rights as a universal concern rose. However, these tendencies will not be put into action when human rights participation will be enabled by the popular culture system. This passion produces energy that could flare up crisis, outrage, and grief, and then the audience becomes deflated and detached (Pruce, 2011).

Additionally, treaties have been designed to stabilize countries facing a human rights crisis. Nevertheless, because of the correlation between these rights the state's authority, some treaties fail to curb the oppressive behavior of the people in a society. Scholars should contemplate the possibility that "complying with human rights treaties depends exactly on the kind of rights in question" (Hill Jr., 2010). Further, human rights are a noble pursuit. It empowers people who are victims of injustice by carrying out their duties while receiving only a little protection. The innovation of common rights attempts to regard the fundamental concerns of individuals irrespective of peripheral attributes to show that democracy amends the disparate deal between the powerful and powerless. The discourse is empowering and potentially subversive. This tension between heightened awareness and the tenacity of the ancient order explains one of the challenges of twenty-first-century global society. Despite the pro-status-quo ideological dogma, the Middle East is undergoing fast change as the last bulwark of an antiquated government. Human rights are a sanguine force that influences modern-day history. The increasing tendency towards justice and freedom is creating a whirlwind of change, and North Korea is on the spot for its 
utterly disappointing human rights record (White paper, 2010).

Following the major global wars, a discussion on universal human rights arose. The monstrous killings perpetrated by the villains of the Second World War signaled the world the value of human rights. Not only were people shocked about the inhumane actions committed by the perpetrators of World War II at the concentration camps, but the bombings of Hiroshima and Nagasaki stood out as evidence of the strong probability that the existence of humans would be exterminated through self-annihilation. Science could not seem to serve its purpose simultaneously, and technology shifted its course, urging humanity to confront its darkest potential. Empirical questions such as "What is human?" and "What is history?" have become the subject of modern-day debate. "The human rights discourse was embedded in an existential aspect. We needed certain mechanisms to protect ourselves from self-aggression"(Pruce, 2010).

Throughout the world, people are concerned about human rights violations. The 1975 Helsinki Agreement guaranteeing fundamental human rights was signed by major powers in the East and West, but it is challenging to monitor compliance with the treaty. Unfortunately, some small nations in the Baltic (Estonia, Latvia, and Lithuania) had no choice recently but to demonstrate against their oppressors. The brave people of Riga and Liepaja, who were born and have lived under a one-party system since 1939, took to the streets demanding their guaranteed human rights (BBC Monitoring, 2014). Also, at first glance, human rights treaties do not affect human rights practice, according to scholars studying international institutions. The Human Rights committees and Council, who are tasked with determining whether they are acting in compliance with the Human Rights Treaties, do the "self-monitoring." Even though their report is forwarded to the Commission, this type of reporting is regionalist in character, and some human rights breaches may be unreported since these committees took action to address the infractions. (Hafner-Burton 2005; Lebovic \& Voeten 2006).

In addition, theories of commitment to the human rights regime and theories of repression adopt many of the same explanatory factors. It would certainly be challenging to make the case that a state's choice to ratify a human rights treaty is independent of its choice to violate human rights (Powell \& Staton, 2009). Along with that, many implementors have carried out human rights since it was drafted. However, there was a conflicting issue between the radical and the legal method. However, as the effects of the cold war fade, some political actors have used human rights as a ticket to join a political action, even if they are not members of a burdened community or an accredited human rights advocate or defender. Human rights organizations, aware that the entire world is watching, position themselves as agents of a just and peaceful global community. Recognizing human rights as a critical issue implies the possibility of a more significant number of people being empowered to defend human rights and dignity (Pruce, 2011).

In addition, interregional inequality had diverse pathways depending on the type of income. Wages and salaries have the greatest and fastest-growing impact on income disparities. The contribution of informal incomes to overall inequality diminishes and interacts negatively with other sources of income that are unevenly distributed; they provide more than half of total interregional convergence in this way. Profits and gains from entrepreneurship had a somewhat decreasing impact on inequality, primarily mitigated by their lower percentage of total income. The most substantial soothing impact was provided by social transfers, although their contribution to convergence had reached its limit. Income from real estate was shown to be the most reliable source of income (Malkina, 2017).

Also, notwithstanding the expansion in global macroeconomic performance in Costa Rica, income inequality has become prevalent. It is currently at its maximum historical value, which differs from other Latin American countries. This rise made significant progress in reducing inequality. In 2010-2014, public sector wages got the most giant slice in the inequality map. In the public sector, wages of those working in public agencies outside central government provided the most, and the private sector drove the most significant increasing skills premium of inequality. Workers with a bachelor's degree make roughly four times as much as those with merely a high school diploma. Non-contributory pensions, for example, have helped reduce inequality, 
although their impact is limited due to their modest share of total household income. The study also calculates the minimal effect of various income sources on inequality, concluding that a rise in salaries for low-skilled workers in the private sector would have the most significant marginal influence on reducing inequality. On the other hand, increasing the earnings of qualified workers in public and private sectors would result in the most remarkable rise in inequality (Pandiela, 2017).

Further, in Britain and France and their colonies, workers and indentured immigrants were not disguised slaves (as much literature of the nineteenth century has argued). However, they had fewer rights than their masters, which made their citizenship an inferior one. It then followed that the Industrial Revolution in Britain had become stronger rather than reduced legal restrictions on labor. Britain and France both linked this labor issue to numerous factors. From the sixteenth to the early twentieth centuries, territorial and colonial expansion caused the demand for labor, together with the growth of agriculture and trade, proto-industrial, and later industrial development, despite demographic growth and slavery, which augmented the available labor force (Stanziani, 2013).

\subsection{Racism and Social Classism}

Accordingly, the features of anarchy are as follows: laws that are not put into effect; forceless and despised authorities; unpunished crimes; compromised safety of abused individuals; unsecured virtue of victims of corruption; not even a government nor justice (Thomas, 1986). Similarly, in Britain today, the racism faced by African-Caribbean people and Muslims is still significantly higher than that of Eastern Europeans. Rotting prejudice against Eastern Europeans does not change discrimination against other groups but creates a scapegoating atmosphere where all kinds of racism are tolerated. The race is socially constructed, but now that it has been established, it is also a social fact - one that cannot be ignored or marginalized by anyone hoping to change our society. The existence of racism undermines all struggles against oppression and thus weakens all those struggling, including white people (Olende, 2018).

Further, if it accounts for moral evolution and cultural variability, a form of principle based on a universal common morality cannot sustain a firm, substantive concept of justice. Moral standing considerations are secondary concerns outside common morality that differs by culture and evolve. To declare that the alternatives are unacceptable in terms of common moral principles is to deny that morality is variable, therefore rejecting fairness as a moral norm. Common morality is seen as a good approximation of a defensible and universal basic morality in this theory. If none of these possibilities are acceptable, and there is no other way to resolve the difficulty we have presented, we're left to consider how much a set of universal moral principles can contribute to ethics and biomedical ethics (Hodges, 2013).

A green economy does not exist in a vacuum. In a complex social ecological system, the green economy is fundamentally about regulating the interaction of humans with the biophysical environment. As a result, human and biophysical aspects must be evaluated together, with special attention paid to their interrelationships. The agricultural sector in a green economy must be sufficiently positioned and in touch with social, economic, and biophysical conditions to be sustainable and give projected benefits in the face of changes in these variables. The African Union's commitment to agriculture and the green economy allows countries to share their experiences in transitioning to a green economy based on renewable energy (Musvoto, 2015).

Also, prohibiting Indians from migrating to Europe was rescinded in 1916. Nevertheless, it was only after the crafting of laws by the International Labor Organization, or ILO, that the treaty was realized or put into effect. Since the ILO, labor protection for workers has become evident, especially in transnational companies. However, labor conditions in smaller industries are still poor. It was only at the onset of the twentieth century that equality in labor rights in both giant and small industries was properly addressed (Stanziani, 2013).

Also, the decline in the United States' labor force participation in 2007 was influenced by the aging population. The recession was also a contributing factor that led to this decline. At a younger age, the decline 
was due to increased enrollment as younger people opted to go back to school. Other contributing factors to this waning were younger working men experiencing health issues and other aspects that prevent them from working. Opioid medication is used by nearly half of the working-age population who are not in the labor force. This downfall in labor force participation and the opioid pain medication prescribed by doctors are interconnected (Krueger, 2017).

Likely, according to Canada's latest Statscan data, their employment rate in June 2014 for working residents was 61.4 percent. A downfall was evident against 63.5 percent in June 2008. These included the working population or people employed as part of the total population. Despite a variety of hypotheses about what caused the downturn, many experts believe it was more due to shifting age and income characteristics than to laborers or workers quitting their occupations to further their education, retire early, or simply be idle at home (Parkinson, 2014).

Aside from that, Indonesia is not yet spared from the clout of corruption despite any attempts to curb it. Indonesians have high hopes that the new administration will bring change to the country's overall development. Indonesians, traumatized by the previous government, which ruled with traces of corruption in almost every state department, attribute this to an unintentional election of a leader. This action means that they elected someone without checking into his background. They believe that choosing a leader accidentally will jeopardize not only their economy but their whole nation as well (Hendi, 2016). Moreover, to understand the conditions necessary for democratic transition, modernization theory was a breakthrough. In the two categories of development, it follows that political development poses a greater inclination to politics. However, in later development, modernization theory is found to be inadequate. But despite the limited features that these two categories of development offer to change the regime, it is still widely accepted in China (Owen, 2015).

Relatedly, Mappens likened the thugs who exploited America's Prohibition, an experiment preventing the establishment of criminal empires among the great cities of America, to Tony Soprano. Most of these thugs were born between 1880 and 1905, all of whom were of foreign origin. Some of these men are Irish, but most of them are Italian or Jewish. The Irish men were ranked, but the Italians were the more popular ones. They were part of the mass immigration from Europe to America during the late twentieth century. As a result, this terrible act of Americanization, which these offenders were successful in achieving, was symbolic since they submerged themselves in society as underworld enemies. (Murphy, 2014).

On the one hand, George Janus Aditjondro remarked that "a former South Korean president with a civilian background, Kim Young-sam, could prosecute the country's two former corrupt presidents, Roh Tae-woo and Chun Doo-hwan." Perusing Soharto for more than ten years, Aditjondro added that the Stolen Assets Recovery Initiative, or SARI, an organization initiated by the United Nations that succeeded in recovering properties stolen by the two former leaders, was geared in two directions. "The (initiative) intends to teach Indonesian and South Korean industries, along with their chaebol, a Korean term for conglomerates. Korean carmakers like KIA and Hyundai have made deals in the past with Suharto's children. " Working with the World Bank and Transparency, the scheme approximated the fortune of Soharto, ranging from 15 billion to 35 billion U.S. dollars (The Jakarta Post, 2007).

Further, Aristotle's famous description of humans and their involvement in politics was that men are distinct from other animals by their ability to speak and their capacity to carry out the ethical convictions. Aristotle regarded the city-state as the ultimate and standardized system of refined existence, as well as the best intermediary through which human potential could be realized (Bowle, 2019). A spirit of stillness and intense reflection enveloped Poland yesterday as the country mourned the death of the man they are convinced was the most extraordinary Pole who ever lived. Thousands of Poles flowed into the churches and to an open-air service in the old Polish capital of Krakow, where Karol Wojtyla studied, was ordained a priest, consecrated a bishop and archbishop, and was appointed a cardinal. Traynor, 2005). "Do not fear," the mourners were told in an echo of the first advice proffered by John Paul to the world's Catholics when he was made Pope 26 years ago 
(Traynor, 2005).

Adversely, prison professors and ethnographers from all over the world have been unable to access Russian jails. Furthermore, legal rhetoric dominates studies on the topic of prisoners' rights. Over the last two decades, empirical and theoretical scholarship has argued that Russian imprisonment is exceptional in studying world penal systems, with research attempting to understand this exceptionality by observing the inertial legacies of Gulag penal culture on modern-day punishment forms. This text tries to refute this assumption, arguing that, specifically in the field of human rights, Russia has a carceral structure that is like that of Western prisons. The article claims that human rights are operationalized as a tool for legal and penal control by probing the cultural, political, and historical variables that underpin how rights are conceived in Russian prisons. Due to the problems that arise from punitive resilience, how rights and penal authority grow through language, and how global penal norms converge across jurisdictions, this is frequently a major new finding in the study of Russian imprisonment. Russia has followed a carceral structure like of Western prisons. Through an interrogation of the cultural, political, and historical factors underpinning how rights are framed in Russian prisons, the article suggests that human rights (Piacentini, \& Katz, 2017).

Furthermore, in Europe, employees' health depends on the government's move to address inequality among workers. Consultation between the employer and the employee to discuss their working conditions is a contributing factor that leads to the well-being of workers, thereby relating social classes to mental well-being. In conclusion, employees need a good and fair working environment where inequality is addressed while improving their mental wellness (De Morteel, 2014). Moreover, according to population health researchers, social class is a "set of attributes" that show the economic capacity of an individual. Class as an attribute is tantamount to an observation of classes limited only to observable factors. As a result, class, as it is defined today cannot be abstracted, calculated, or mediated to be classified as a personal attribute. Linking it to Marxism, classism is an obscure social structure like exploitation. However, neo-Marxism sees class as a prime factor in determining inequalities in health issues. Further, it sees class as an opportunity to maximize productivity and power for higher classes. Thus, researchers do not take neo-Marxism positively. For the past 20 years, classism has affected the health of workers. Taking class as the cause of social inequalities and properly addressing it will reduce health inequalities (Muntaner, 2015).

However, the essential duty and responsibility of the capitalist state are to keep a complex and multi-faceted economic system together, coherent, and stable. Because the state is devoted to maintaining the integrity of a system in which bourgeois capitalists play a dominant role, the dominant class's primary role, position, and power are ipso facto protected and preserved. This practice is true even when state power is not wielded on their behalf by these classes, and even when certain classes and goals of the state-controlled government are run in opposition to bourgeois capitalism's evident desire. It also serves as a balancing and conflicting area of power (Solo, 1978).

Relatively, at the height of a dramatic rise in the gap between the rich and the poor in the United States, Ornstein (education, St. John's University) comprehensively presents the history of inequality, including divergent perspectives, current data, and progressive measures to fight this second "Gilded Age." The massive data set includes statistics such as the top $1 \%$ owning roughly $33 \%$ of all U.S. wealth and only $3 \%$ of youth from the bottom quartile attending elite colleges. Most Americans struggle to get by; they have lost their competitive edge, and "political and business thugs" prevail in Washington and Wall Street. Ornstein argues that education has limited effectiveness due to the enormous gap. As a liberal centrist, the author argues for such reforms as increasing progressive taxes, retaining estate taxes, and providing universal health insurance and college tuition. The book is written in a conversational tone, both its strength and weakness; it is accessible but needs editing; redundancies abound (Borchert, 2008).

Along with that, every country benefits from a large and thriving middle class. It promotes both economic and social, and political stability. In general, four explanations for the declining middle class have been proposed: 
(1) demographic factors, (2) structural or microeconomic factors, such as the loss of middle-class manufacturing jobs and the decline of labor unions, (3) macroeconomic factors, such as business-cycle unemployment, and (4) changes in public policy (Pressman, 2007). In addition, several categories of social class in the U.S. today are described. The classes include the inferior, poor, working-class, middle class, upper-middle-class, owning class, and ruling class." Generation after generation, poor people lack basic needs; most are uneducated or unemployed. Poor people lack sufficient money to get along with their needs for food and medication. Many have dropped out of school and are unable to secure ongoing work. Many people do not have bank accounts and are therefore unable to obtain credit. Working class people usually get their basic needs met, but they often have to save up for and choose between simple luxuries, such as eating out versus buying new clothes for the kids. In the past, few went to college; now, many go to vocational school or community college and hold "blue" or "pink" collar jobs (Bradley, 2011).

Additionally, many middle-class people go to college (often state schools) and hold "white-collar" jobs or become owners of small businesses. Many buy modest homes, although this now often requires a two-income family. They save up for luxuries (e.g., summer camp and a new car (Ornstein 2011). Apart from that, many upper-middle-class people go to private schools, pay people to work in their homes (e.g., housekeepers and gardeners), and take a fair amount of luxury for granted. They hold "professional jobs," such as architects or doctors. Children often receive inheritances from their parents. Owning class people grow up in families with substantial ownership of private businesses, land, or shares of stock in corporations. Their adult lives frequently involve substantial time and responsibility in managing their financial assets. Most have enough money to support their families even if they do not work (Hancock, 2000).

Beyond the orthodox Marxist account built on a particular reading of the Communist Manifesto, first-generation neo-Marxist class theorists expanded how beyond the orthodox Marxist account that is grounded in a careful reading of the Communist Manifesto. However, the shifting reality of capitalism since then has highlighted the limits of their respective orthodoxies. This article addresses these constraints with the help of Bhaskar's critical realism and Gramsci's philosophy of praxis to aid the transition to second-generation neo-Marxist class theory. This re-conceptualization is followed by a critical examination of Beck's claim that individualization leads to capitalism without classes for themselves. Considering the preceding arguments, the paper finishes by rethinking the class (Neilson, 2018).

Over the last half-century, a study looked at the relationship between economic concepts and policymaking in Africa. It discussed how economists working on Africa had shifted their focus from structuralist-developmental and neo-Marxist perspectives in the 1960s and 1970s to a more eclectic mix of neo-institutionalism, growth orientation, and welfare interests in poverty and redistribution issues in the 1980s and 1990s. While these trends in development thought are not unique to Africa, they have received little attention on the continent (Mkandawire, 2014). Further, increased economic growth did not follow trade liberalization in Sub-Saharan Africa (SSA), for reasons that have not yet been identified. Two factors that may be involved in the failure of economic growth in SSA are foreign direct investment (FDI) inflow and physical infrastructure. The purpose of the study was to find out what university professors with experience in SSA policy thought about the significance of FDI and infrastructure on SSA's economic growth since 1980 in a trade liberalized environment. Semi-structured interviews were conducted with eight academic researchers involved in teaching in universities in SSA and seven academic researchers of African origin involved in teaching in U.S. universities (Ahmed 2016).

Latin America is in the midst of another catastrophe. A brown tsunami of peripheral fascism replaced the so-called "pink tide" of progressive regimes. The literature is replete with short-term theories for the pink tide's "ebbing." They concentrate on the flaws of moderate-left regimes, ignoring the cyclical nature of capitalist crises and the authoritarian nature of the administrations now in power. This paper returns to the main question presented by dependence theory half a century ago searching for a comprehensive, long-term explanation: is capitalism's development viable in Latin America? The key to answering this question is a development concept 
that encompasses non-convergent transformations (Oliveira, 2019).

While studying liberation theology, a decolonial theoretical discourse represents the beginnings of Latin American decoloniality. The problematic issue of the role played by Marxism in it since its inception has been initially and innovatively reinterpreted by looking at the points in common between Gutiérrez's and Mariátegui's thinking from a decolonial perspective. On the other hand, the revisionism of the classical question of liberation theology's lack of a hermeneutic and epistemological methodology in terms of the concept of "bidirectional hermeneutic dialectics" not only demonstrated the reality of liberation theology's hermeneutics and epistemology, but also demonstrated the problems posed by the most important theoretical contributions on the subject made by liberation theologians themselves (Mkandawire, 2014).

\subsection{War and Conflict}

It was encouraging when Gorbachev acknowledged Stalin's crimes against the Russian people and other nationalities. It gave hope for further liberalization in the Soviet Union and the countries under its sphere of influence (Toronto Star, 1987). Twenty-one additional bodies have been discovered in Myanmar, this time from burned-out dwellings. 9,000 Muslims have been stranded in camps as tensions persist. President Thein Sein has asked the army to restore peace in Meikhtila, which has been rocked by sectarian riots. The Muslims displaced by violence are facing an acute food shortage at present. The number of those who have died has crossed 32 . In communal disturbances between Muslims and Buddhists over the last three days, thousands of Muslim homes, as well as many mosques, have been set ablaze. Anti-Muslim riots in Myanmar have been continuing for the past six months (BBC Monitoring, 2018).

Without a doubt, the idea of France being usurped by Islamic forces is a metaphor used by Le Pen to note that this can be possible. It would be an eye-catching picture if "the veil would be imposed on all women" had Paris lost the war against "Islamist Totalitarianism." Implausible as it may seem, the increase in the number of immigrants and the Islamic attacks on Paris call for discernment among the electoral body. (Rubin, 2015). Furthermore, the protection of fundamental human rights has remained one of the most pressing yet elusive goals of the international community. Though fashioned to counter one of the most insidious dangers that threaten the very foundation of modern-day international order, the number of deaths associated with armed conflict and, therefore, the fatal accidents caused by international warfare has remained frightening. With the demise of Ghaddaffi, world attention shifted to Syria, mainly because it concerns intervention to put a stop to the protracted killings and, therefore, the human rights violations as a result of the heavy crackdown on citizens by the Assad regime. However, the lack of the international community to effectively answer the Syria crisis through the humanitarian intervention responsibility to guard doctrine (RtoP) and therefore the geopolitics between the U.S., Russia, and China is dangerous stalemate remains within the Syria crisis (Erameh, 2017).

In a different scenario, a grass-root movement from within the proper wing of Christian opposition to the Syrian military security emerged to campaign for the recovery of the disappeared in 1989. Beginning as a blatantly political campaign, SOLIDE evolved into a human rights-focused NGO in the aftermath of the war, a transformation made feasible only by an alliance with a group of mothers of the disappeared; gender stereotypes allowed SOLIDE to exist as basically apolitical. With the establishment of a protest tent in downtown Beirut in 2005, after the Syrian withdrawal. An examination of the various stages of activism reveals that in Lebanon, the lines between humanitarianism, which is often motivated by spiritual inspiration, and human rights activism have become blurred (Yazdi, 2020).

Also, Paulo Freire (1970), a Brazilian education activist, believes that oppressed people must gain critical consciousness about their circumstances through conversation to effect social change. He believes that discourse allows for introspection and the development of unity, which are necessary instruments for reworking society. Because they are bound by a commonality of racial oppression, teachers of color must engage in cross-race conversations about manifestations of racial injustice in K-12 schools and develop ways for change. Through 
cross-race dialogues, the ladies were able to widen their global awareness of racial injustice and plot solidarity building among various kids in urban classrooms. This study underscores the value of intercultural discourse in the classroom by demonstrating the knowledge and insights of instructors of color (Kohli, 2012).

In particular, every phase of global capitalism has been accompanied by genocide, including Europe in the twentieth century. Theoretically, the colonizers' and states' macro-construction of racism across time as genocidal conquest perpetrators must be accounted for (Fenelon, 2016). Importantly, "the Louisiana Purchase, the blatant genocide already mentioned in California, and numerous genocidal events against various Indian nations, such as the Mankato hangings in 1862, the militia massacre at Sand Creek in 1864, and the perfect coda of Wounded Knee in 1890," are all examples of similar 19th-century examples. These symbols signified "freedom" for settler-colonialist pioneers, death and ruin for Indian nations and peoples denied citizenship. A new state established on genocide is none more powerful than California (Fenelon \& Trafzer, 2014).

Furthermore, genocide and ideological racist conceptions were important components in the 500-year evolution of capitalism through its various phases. The Western system's legacy of institutional racism and legal genocide questions the entire ideological underpinning of contemporary neoliberalism. What we can be sure of is that the world's two most ideologically and demographically destructive societies - Nazi Germany for the Holocaust and western colonialism for the genocides against American Indians - developed and maintained race, racism, and genocide as state policies in the service of world empire and globalization. From the beginning, the construction of race and the establishment of various types of racism were worldwide and genocidal. We need to broaden our analyses to account for the macro-construction of race and systematic racism, which is frequently genocidal, throughout the contemporary world-lengthy system's history (Fenelon, 2016).

Moreover, genocide is widely considered to be a species of mass murder that involves the intentional destruction of national, ethnic, racial, and religious groups. Members of targeted groups are killed because of who they are rather than what they have done, and the groups themselves are annihilated based on traits and conduct they are not, in fact, responsible. According to this view, the concept of genocide picks out a phenomenon that is both immoral in its necessity and distinctive in that it is the most heinous international crime. If the concept were defined in any other way, it would lose its normative force, and, worse still, it would imply that such historical events as the holocaust are morally equivalent to crimes that are far less serious (Abed, 2011).

Besides, it is easy to see how the term "genocide" appeals to individuals who are enslaved by Mircea Eliade's "fear of history," the traumatic sense of group enslavement or destruction. The horror of disappearing from or losing agency in "history" (Moses, "Genocide and the Terror of History") is a structure of feelings. Since its introduction in international talks in the second half of the 1940s, genocide has become a catch-all term for this emotive aspect of consciousness in all world's regions (Dirk, 2013). Syria's civil war began as a nonviolent movement against the country's president, Bashar al-Assad, during the Arab Spring in 2011. It eventually escalated, destroying the lives of Syrians, ruining cities, straining global politics, and spurring diplomatic efforts that are constantly questioned as the world witnessed the horrors of ongoing warfare. North Korea's government does not like people from outside the country to find out what is going on. It shares a border with South Korea, and the two countries have not gone on with each other for a long time since their separation. Accordingly, North Korea was duly created on September 9, 1948, following the end of the Second World War, along with another country called South Korea. The political differences between the two competing states led to a horrific war in 1950 that lasted three years. Since then, North Korea and South Korea have been enemies (Newsround, 2018).

Castro eradicated legal discrimination in the Caribbean, brought electricity to the countryside, ensured full employment, and advanced the causes of education and health care, in part through constructing new schools and medical facilities. The wrong side is that Castro closed opposition newspapers, jailed thousands of political opponents, and made no move toward elections. He also restricted the amount of land a person could own, outlawed private businesses, and presided over housing and consumer goods shortages. Due to the lack of 
political and economic options, hundreds of thousands of Cubans, including many professionals and experts, left the country, many of them for the United States (History.com, 2018).

Also, since the Khmer Rouge seized power in April 1975, people have argued over the actions and intentions of the communist regime in Cambodia. During the revolution, scholars and journalists debated allegations that the Khmer Rouge was committing genocide. Even after communist Vietnam toppled the neighboring regime, the debate remained fierce. Much of the positioning by academics, publicists, and politicians seem to have been primarily motivated by political purposes (Beachler, 2009). With the help of international training and aid, today, three decades after the toppling of the Khmer Rouge, dedicated archivists at the Documentation Center of Cambodia (DC-Cam), along with colleagues at the Tuol Sleng Genocide Museum, are preserving this extensive cache of Khmer Rouge records. The records are the primary pieces of physical evidence currently being used in a hybrid tribunal called the Extraordinary Chambers in the Courts of Cambodia (ECCC), jointly operated by the United Nations and the Royal Government of Cambodia. The tribunal is unique for two reasons: first, legal decision-making is shared unequally between Cambodian and United Nations judges, with decisions requiring a "supermajority" from the Cambodian judiciary; and second, victims are allowed to file claims as civil parties to the case. The tribunal has indicted five former Khmer Rouge officials for violations of Cambodian and international law, including crimes against humanity (Caswel, 2010).

The Turkish-Armenian rapprochement process has generated severe concerns in Azerbaijan at both the general public and governmental levels. The actual worry was how the development in Turkish-Armenian relations would affect the resolution of the Azerbaijani-Armenian Nagorno-Karabakh conflict. The immediate explanation for the closure of the Turkish-Armenian border was Armenia's 1993 occupation of Kelbajar, one of the seven adjunct districts to Azerbaijan's Nagorno-Karabakh region. Baku's resistance to the normalization process was and is predicated on the argument that the settlement of the Nagorno-Karabakh conflict and, therefore, the opening of the Turkish-Armenian border should, given their connection, move forward in parallel. The normalization process saw an agreement to determine mutual diplomatic recognition, culminating in the Zurich Protocols in October 2009, signed in the presence of the Russian, French, and Swiss foreign ministers and the U.S. Secretary of State. However, because neither party has approved the protocols, the process has been effectively halted pending resolution of the Nagorno-Karabakh conflict. The Armenian side reacted angrily to Prime Minister Recep Tayyip Erdoan's remark that Turkish parliamentary ratification was contingent on progress in conflict resolution six months after the signing (Shryev, 2013).

Alternatively, the United States laid the groundwork for the legal destruction of Indians by excluding them from citizenship. Examples of genocide include Washington's destruction of central Onondaga (peace) fire-keepers of the Haudenosaunee confederacy (five nations) and the forced removal of the Cherokee nation and the "five civilized tribes" in the southeastern United States. The Haudenosaunee confederacy (Iroquois) managed to stay intact after the "French and Indian War." During the U.S. Revolutionary War, the Mohawk were pulled into the English orbit, with the Onondaga maintaining neutrality. But General-President Washington viewed the Indian confederacy as a threat and sent an army under General Sullivan to destroy it (Fenelon, 2016).

Considerably, Korsch considered Marxism to be the theoretical agency of the proletariat. He famously disagreed with theorists like Lenin and Kautsky, who believed Marxism to be an "objective" science, developed external to the working class and imported into it. Despite their political differences, Korsch recognized that both Lenin and Kautsky had distorted Marxism by portraying it as a positive "science" unrelated to the historical proletariat. Korsch, on the other hand, claimed that Marxism was the philosophy of the working class, the proletariat's organized class consciousness (Meisenhelder, 2001).

On October 10, 2007, the US House of Representatives Foreign Affairs Committee was expected to approve a bill called on the USA to recognize the Armenian genocide. However, President George W. Bush promptly urged United States legislators not to pass a resolution declaring the killing of Armenians by Ottoman Turks to be genocide. Just before the Foreign Affairs Committee began debating the resolution, Bush warned of the 
enormous and negative impact of such a resolution being passed, not only on the USA but worldwide, claiming that "This resolution is not the right response to these historic mass killings, and its passage would do great harm to our relations with a key ally NATO and in the global war on terror" (Goldenberg, 2007).

According to Rob McCoy, the essence of freedom is the proper limitation of government. The smaller the citizen, the larger the government. To protect the rights of the citizens, the government needs to be limited. He added that the Declaration of Independence was a radical response to a monarch because a king thought of everyone else as his subjects and that people were born to serve him (the king) (Geilber Markel 2016). Sovereignty is not political, but it holds a special status. It is a foundational concept, a worldview-conceiving political concept. There have undoubtedly been philosophers, legal scholars, and political intellectuals in the past and present who have considered alternatives to sovereignty thinking, or who have portrayed political events and experiences as explicitly problematic for sovereignty-centeredness. Hannah Arendt's work in general and her description of the American Revolution and founding history as decidedly anti-sovereign is undoubtedly one of the more prominent examples of this. However, in political and legal thinking, they have been unable to prevail because they have failed to provide an adequate alternative to bonding capacity (Volk, 2019).

The Kashmir conflict is one of the longest-standing and most intractable between India and Pakistan (over Kashmir) and between India and the people of Jammu and Kashmir (in Kashmir). The conflict's dynamic character has an impact on many people's lives in political, social, economic, and cultural arenas. Beginning from the analyses provided in "Memory and hope: new perspectives on the Kashmir conflict," Race \& Class 56, no. 2 (2014), the author looks at the huge scale of human rights violations. As he details the toll for 2018, he argues that one should not view the conflict as simply that between India and Pakistan over territory, but as continued and continual violations of the people of Kashmir (Bhat, 2019). Based on this literature, the holocaust has had a significant impact worldwide, even years after it occurred. Not only did it cause political tension during the time of its occurrence, but even years after, especially since even the study of the holocaust has brought about political tension in some countries. Aside from that, it also influences on various citizens and governments about the holocaust. The memory of and the study of the holocaust cannot be materialized without considering political considerations. On the other hand, these factors contributed to the historical consciousness of various people about the holocaust. These include not only the study of the holocaust itself but also films and movies related to it.

\section{Methodology}

\subsection{Research design and procedure}

I applied a descriptive qualitative method in this research study. The holocaust is associated with exploitation, and it is hardly acceptable to some. Marx established links between reality's phenomena to clarify social totality. He considered that it is the class conflict that initiates transformation in societies (Soares et al., 2013). In the Karl Marx memento, it was stated that people should get what they deserved, which is called equality and should not force others to do their bidding, which is justice. This principle of Marx only shows that fairness is the key to living in this world peacefully and harmoniously. The actual experiences and feelings of people concerning a particular phenomenon being described are the primary concern of a researcher in a phenomenological study. The above statement revolves around people who share the same experiences of a specific phenomenon or event. This prompts the respondents who experienced the event to generalize what they felt and saw. As such, the idea is dependent almost exclusively on lengthy interviews with critically selected sample participants (Giorgi, 2009; Moustakas, 2014; Raagas, 2010).

I used a phenomenological approach because I am curious about how things appears to one's consciousness. Through reading and viewing short films and documentaries, I wanted to bring out the best ideas from my participants by letting them experience the lives of the characters in a story. I was also curious to hear how the 
participants described that experience and shared their observations, feelings, and behaviors in response to it. Phenomenology is the most appropriate instrument to utilize in this study to visualize and investigate the first-hand experiences of my respondents who read and watched Holocaust films.

Phenomenology first came into use in the first decade of the twentieth century under the impact of the German Philosopher Edmund Husserl., who aimed to establish a rigorous and unbiased approach that appear to arrive at an essential understanding of human consciousness and experience (Fochtman, 2008, Lopez \& Willis, 2004; Wojnar \& Swanson, 2007). To conclude, phenomenology aims to gain a deeper understanding of the meaning of the daily experiences of the individuals involved in the study (Polit and Beck, 2008) and "direct the understanding of phenomenology which is deliberately experienced by people themselves" (Polifroni \& Welch, 1999).

This claim was furthered by Van Manen (1990) when he said that "phenomenological research does not develop a theory but provides insight into reality and brings us closer to the living world." It may ask the following questions: "What was this experience like?" (Laverty, 2003). "What is this experience all about?" "What does it feel like?" (Van Manen, 1990). What is the core of this phenomenon as experienced by these individuals? What does the phenomenon mean to those who witnessed it? (Polit \& Beck, 2008). By employing Husserlian phenomenology, bracketing is also applied where the researcher can spare rooms and set aside personal biases, assumptions, and presuppositions. (Gearing, 2004). This process then keeps known and standard information from the respondent as they try to describe the phenomenon idependently. Researchers should not impose any expectations on the procedure of collecting data or data structuring (Speziale \& Carpenter, 2004).

As previously stated, bracketing is used to reduce assumptions and avoid putting presumptions into practice that could compromise the dependability of an investigation. This is a very common misinterpretation. Bracketing in phenomenological research, if applied appropriately, may yield a precise outcome that will make the study successful. Knowing this, the researcher must apply utmost caution in separating his conviction from the data gathered. The core is the perception and experiences of the respondents as they narrate it and not the stored or acquired knowledge of the researcher (Starks \& Trinidad, 2007; Taylor, 2012; Taylor \& Francis, 2012; Tufford \& Newman, 2010). The participants' perception about the holocaust, how they relate those experiences with the issues at present and, the insights that they have learned were the core of this investigation.

Through phenomenological reduction, "the researcher simply reduced the realm from how it is perceived naturally, with all biases and judgment, to a realm of pure phenomena" (Dowling, 2007). With that, we can bring out the soul of the phenomenon as described by the respondents using their own words. The method examined and analyzed the phenomenon through the subjective views of the participants. Subjectivity is considered and expected in this method because humans have their own emotions and views. Moreover, looking at these views, they must interact with the world. The researcher stated that the participants' personal experiences are the focus of this investigation, therefore preserving the researcher's point of view is critical (Creswell, 2007).

Despite all of the given definitions and applications, the phenomenological approach remains indispensably helpful in identifying deep concerns. It was crucial for me to personally respond to my respondents' insights about the holocaust, not only because it is a worldwide phenomenon but because we have been a part of it. I expected to excerpt familiar ideas about the student's feelings, perceptions, and insights as they read the stories, adapt these experiences as described, and connect them with the universal principle of the experience. Considering the "multiple realities" that the participants had gone through, the "insider perspective" was the key to understanding what was going on (Davis, 2007).

On the other hand, qualitative data can be obtained through conversations, interpretations, and documents (Creswell, 2007; Giorgi, 2009; Locke et al. 2010; Suter, 2012;), highlighting two data collection procedures. Utilizing in-depth interviews, focus group discussions, and note taking, I put the weight on scrutinizing the particulars. "What one seeks from a research interview in phenomenological research is as complete an outline as possible of the experience that a participant has lived through" (Giorgi, 2009). 
Through phenomenology, the presumptions of the students who read and watched the documentary on the stories of the holocaust were saved. These presumptions were compared with the actual data gathered after the researcher interviewed the respondents. The researcher's preconceptions were also described and reported in this chapter. Observing flexibility and openness and allowing a considerable amount of ambiguity, as observed by (Straus \& Corbin, 2008), will yield a positive output. The themes extracted from the responses of the 12 participants in the in-depth interview and eight from the focus group discussion were grouped. Consistent with Creswell (2006); Giorgi, 2009; and Kvale and Brinkmann (2009), in qualitative research like phenomenology, it is recommended that for in-depth interviews, researchers interview 5-25 participants who have experienced an equivalent phenomenon, if one wants to realize the goal of representativeness and generalizability as a criterion, from a small number of research participants. Nevertheless, sample sizes of 10-15 participants are adequate, provided participants can provide detailed descriptions of the phenomena (Speziale \& Carpenter, 2007). Moreover, Hancock et al. (2009) stated that focus groups are considered adequate and work exceptionally well with approximately eight people.

\subsection{Research Participants}

Choosing my participants was the first thing that I considered before I started planning for the details of this study. Since I am teaching literature and with the idea of purposive sampling based on a criterion (Richards and Morse, 2006; Saunders, 2012; Speziale \& Carpanter, 2007), I chose the Grade 11 senior high school students to be my respondents. I specified the selection and chose only regular students and officially enrolled as Grade 11 students. Before I started the study, I had already identified some of my participants. The participants were senior high school grade 11 students taking the subject $21^{\text {st }}$ Century Literature of the Philippines and the World, which I chose through purposive sampling. I based my selection on a pre-selection criterion significant to the study (Richards \& Morse, 2006; Saunders, 2012; Speziale \& Carpenter, 2007).

I also asked my school head to allow me to conduct this study among our Grade 11 students. To obtain a good quality of qualitative research, I opted to get just a considerable number of participants for my research, with 12 participants for the in-depth interviews and eight participants to engage in focus group discussions. Focus groups can work well with approximately eight people. I believe that this is already a substantial number of participants, suitable to give credible information and significant results and findings (Hancock et al., 2009). Moreover, Creswell (2006) suggested that "researchers could adopt 5-25 individuals who had experienced the same phenomenon for in-depth interviews." According to Englander (2012), what matters is how the researcher draws out the participant's innermost sentiments and sensations when he watches or witnesses the event being examined, not the quantity of participants. After all, even proponents of developmental psychology like Freud, Piaget, and Skinner established their principles with respondents and without formal statistical interpretation (Giorgi, 2009; Kvale \& Brinkmann, 2009).

Prior to the face-to-face interview, I conducted initial meetings with my participants. Because I was their teacher, they were a little concerned that what they said would have an impact on their grades. I used this opportunity to explain the procedure they will be going through, why I was conducting this study, and why I chose them as participants. I made them feel that they are an integral part of my research and that the outcome of my study depends on their responses. So, I addressed every inquiry they raised and made them feel comfortable explaining that consent is necessary because they are still considered minors. Most importantly, their grades are no affected after all. This also bought me some time to review my questionnaires. Again, the fact that I am their teacher made it easier for me to distribute my questionnaires in advance so they could ponder on it before the actual interview. Making your participants comfortable and at ease could make you and your respondents establish a good rapport. In conducting research, developing rapport and empathy is good because the respondents can respond best to the questions if they are comfortable with the interviewer. Thus, the positive outcome is expected (Bloom \& Crabtree, 2006).

Only bonafide Grade 11 students who were taking the "21 ${ }^{\text {st }}$ Century Literature of the Philippines and the 
World" subject was included in my study. Irregular students who are taking " $21{ }^{\text {st }}$ Century of the Philippines and the World" as a back subject were not selected to participate in the study. Considering that they are only high school students, thorough preparation was done to ensure that they will not be traumatized or feel nervous. They may not be that knowledgeable enough to give a spectacular response, but I assured them that I do not need the genius to a result. I simply required their opinions and thoughts as Grade 11 students to complete this investigation. I also considered their level of thinking and exposure to the real world when I asked them about their insights. I assured them that as their teacher, it is my responsibility to keep their responses with utmost discretion and that they will not be judged whatever their answers are (Silverman, 2006).

I told my students that it is natural to meet challenges as we progress with the study, like watching some films with human rights violations or somewhat violent content. To ensure psychological stability among them, I watched it with them. I allowed them to ask me anything cloudy while watching, and I explained the problematic scenes. I needed to do that because the data that they would provide is the soul of my inquiry. I promised them that their participation and support would change their opinions of the Filipinos who helped in the rescue, the Jews who had been rescued, and the professors who would analyze the accounts.

\subsection{Data Analysis}

Analysis of data in a research study involves summarizing the mass of data collected and presenting the results in a way that communicates the most features (Hancock et al. 2007). The data were analyzed using a method that included data reduction, data display, conclusion drawing, and verification (Zhang \& Wildemuth, 2007), with qualitative content analysis defined as "any qualitative data reduction and sense-making effort that takes a volume of qualitative material and attempts to identify core consistencies and meanings.". Data reduction is the construction of data from the transcriptions, taking off information which is not essential and transforming it into a comprehensible material, easily understood by many (Namey et al. 2007; Paul, 2006; Suter; 2012). This pairing and sieving of data are called thematic analysis, a form of sorting and categorizing. With data reduction, I employed the expertise of a professional data analyst assigned to me by the university to ensure that we get the right analyst in the field we are studying. I grouped the responses and submitted it to the analyst, where she analyzed the data and came up with the themes where I based my discussion on the findings.

I presented the data, which was analyzed and grouped through a graphic presentation which is commonly termed as data display, where it is shown through "matrices, charts, graphs, that would enable the viewer to draw his conclusion" (Suter, 2012). The data that the researcher gathered is presented, taking note of whether these data are connected to other themes or ideas. Doing it in this style enabled the researcher to scrutinize the procedure closer. It is gathering all information and laying it out for everyone to see even details that are not noted when the data were first grouped and analyzed (Namey et al.; Paul. 2006; Sitko, 2013).

The lens was interpreted based on the related literature where the study was anchored. Two expert and independent readers assisted the researcher in forming a triangulation team. The team studied and analyzed the data, comparing their findings to identify discrepancies in interpretation and gain a deeper and broader understanding of how they perceived the issue or phenomenon. Further, triangulation was employed to ensure the validity of the data by using more than one person to collect the data to increase its reliability (My-Peer Toolkit, 2010; Speziale \& Carpenter, 2007). If all their findings arrive at the same conclusion, then the researcher can confidently declare success. The researcher did not rely on one version of the analysis only. The researcher opened a point for argument and confirmed with the analyst and other professionals involved in the study to validate the analysis that transpired (Sitko, 2013).

\section{Results}

Key Informants. Students from Pipisan Maug National High School, specifically Grade 11 students from Section Narra and Section Mahogany, responded to this survey. The 20 main participants were Grade 11 Senior 
High School students who shared common knowledge of literary analysis and read or watched the same Holocaust stories. These participants answered the same questionnaires and were presented with the same circumstances, reading materials, and documents to draw their perceptions and insights. These data were obtained through interviews and discussion or focus group discussion, as required by qualitative research.

In depth Interview. There were $12 \mathrm{key}$ informants in this group, three males and nine females, who were all Grade 11 students at Pipisan Maug National High School. As a result of the confidentiality and ethical considerations, each participant was given a pseudonym when the data was presented and when the findings were presented, as Bernal (2014) suggested. The pseudonyms were given to compliment the physical attributes and attitudes portrayed during the data collection process, where a face-to-face interview was conducted. To illustrate, Brunette was named because she has dark hair, yet she has a fair skin complexion. Skinny was named after her body structure, which is thin. Shy was the participant who barely talked; she only talked when being asked. On the other hand, the participant who has an eye for a painting and can sketch objects is called an artist. A top student leader was one of the participants and, thus, was called the leader. Just like the seven dwarves, one of the participants is always happy; she is always showing her gorgeous smile, so I called her happy. One of the participants, who is tall and on the school's basketball team, was given the nickname "long legs." Pouty was named after the pouty lips of Angelina Jolie because her lips look the same as the actress's lips. Friendly was the participant who made everyone at ease during the interview. She makes everyone feel comfortable. "Pretty was named for the participant who is a campus crush because of her pretty face. Lastly, "tall" is the tall participant but has no athletic abilities, just plain and tall.

Focus Group. In this grouping, pseudonyms were also assigned to each participant. This girl was given the title "Queen" because she had a queenly bearing and was always innovative and witty. Petite was also given to this not-so-tall girl but knowledgeable about the stories because she downloaded some of the articles and read them to expand her knowledge. Coincidentally, the best friend of Petite was a tall and slender girl, so she was called Slender. Techy was named such because he is adept at using gadgets and apps; he is the IT expert in the group. Kuya is the oldest among the participants. He is a recipient of the Balik Eskwela program and serves as a big brother to all. Player is named after her achievements as a softball player and always gets the "player of the year award." Writer is an avid fan of Korean dramas who knows how to write scripts and short stories, thus the name "writer." And Innocent is the participant who was not exposed to city life because she lives with her grandmother, who is an old-fashioned woman

\section{Table 1}

\section{Participants' Information}

\begin{tabular}{llll} 
Name & Age & Gender & FGD/IDI \\
Brunette & 18 & Female & IDI 1 \\
Skinny & 17 & Female & IDI 2 \\
Shy & 17 & Female & IDI 3 \\
Artist & 18 & Male & IDI 4 \\
Leader & 16 & Male & IDI 5 \\
Long legs & 17 & Male & IDI 6 \\
Happy & 17 & Female & IDI 7 \\
Pouty & 20 & Female & IDI 8 \\
Softy & 18 & Female & IDI 9 \\
Friendly & 19 & Female & IDI 10 \\
Pretty & 18 & Female & IDI 11 \\
Tall & 17 & Male & IDI 12 \\
Queen & 17 & Female & FGD 13 \\
Petite & 17 & Female & FGD 14 \\
Slender & 16 & Female & FGD 15 \\
Techy & 17 & Male & FGD 16 \\
Kuya & 20 & Male & FGD 17 \\
Player & 16 & Female & FGD 18 \\
Writer & 17 & Female & FGD 19 \\
Innocent & 18 & Female & FGD 20 \\
\hline & & &
\end{tabular}


This portion of the research provided a detailed explanation of the findings where the research questions formulated by the researcher were answered. The following questions, to wit:

RQ 1: What are the revealing perspectives of Filipino learners on the Stories of the Holocaust?

RQ 2: How do the learners relate the stories to social issues at present?

RQ 3: What insights ton the stories that the learners learned?

The general overview of this chapter is discussed in the succeeding pages, from the participants' data to the conclusions arrived at.

The fruitful exchange and sharing of ideas afforded the participants to express their feelings and perceptions about the stories of holocaust that they read and watched. I expected them to give similar ideas surprisingly, their responses came in variety. There are ideas that other participants failed to express because they got confused with the correct word to say however, upon hearing others' expression, they immediately merged into the discussions by enhancing the said idea. Moreover, the focus group discussion took place inside the reading center of the school where the researcher is teaching. As Creswell (2012) suggested, I used my mobile phone as a recorder alongside a notebook to record interview notes and FGD. I asked the participants' permission to be interviewed with a recorder in the informed consent, which they immediately approved. All of them were cooperative enough to comply and acknowledge the application.

In addition, the in-depth interview and focus group conference were both held in the Reading Center, a room isolated from other classrooms because, as the name implies, it is the room where reading is remedied, so it can be assured that the room is conducive to serious discussion. As Boyce and Neale (2012) suggest, "using a tape recorder and a notebook" to record the interview is a good idea. However, to blend in, I used a video recorder, so the facial expressions and emotions will also be captured. But before the recording, the full consent of the participants to record the session through video recording was obtained. To reduce consent, an informed consent form was sent to them and their parents, incorporating the fact that the interview would be recorded. The informants had fully agreed to and approved the consent form for one important reason: to conceal their individual identities.

\subsection{Categorization of the Data}

Upon accomplishing the IDI and FGD, the information gathered was transcribed, translated, and analyzed. The coding process followed. The information was chunked into themes to generate descriptions as well as categories. The data categorized corresponding to the research questionnaires are termed as the major themes. These are the responses that, when grouped together, denote a familiar concept. Responses that incongruent with the emerging themes are eliminated. The core ideas are the responses that support the themes. These are the responses as told by the participants in their own words. To delete unnecessary information from the transcription, data reduction was employed to convert this data into essential and logical material simply understood by many (Creswell, 2012; Moustakas, 1994). The categorization and sorting of the information obtained was aided by the principles of thematic analysis.

Reduction, on the other hand, condenses voluminous information into a briefer and more concise form that is easier to comprehend. I accounted for the data when interpreting the report, and then I accurately wrote the interrelationship. A comprehensive explanation was given to the participants to understand the basis of the interpretation (Lincoln \& Guba 2012). Credibility, confirmability, transferability, and dependability, as defined by Lincoln and Guba (2012), were meticulously observed to ensure that trustworthiness is embodied in my study. To attain credibility, I printed a copy of the interview guide and distributed to the participants weeks before the interview. This is to allow them to connect the event they are about to respond to the circumstances being asked in the questionnaires. I also asked for feedback should there be things they want to change. Luckily, 
no one disputed the procedures, and they all signed the informed consent together with their parents.

For peer debriefing, I sought the assistance of my co-teacher, who is also conducting her study to categorize the emergent themes and categories. The debriefing cleared up some ambiguities and clarified the terminologies to be used for the themes and categories. Triangulation was accomplished because the study had more than two sources of information (Stanzia \& Patton 2010), such as the readings from the related literature, the key participant, and the FGD participants. In dealing with dependability and conformability, I must set aside my personal opinions, assumptions, and judgment to agree on the principle that "confirmability refers to how well the results were confirmed by others over time" (Ramsey, 2010). And that confirmability is the application of objectivity. Suter (2012) Adherent to these principles, I used the bracketing approach to suspend personal bias.

To achieve transferability, I provided background data to establish context. As their literature teacher, I explained to my participants the key information that they needed to know so they could provide the correct information that could be generalized during the analysis. As Gasson (2004) theorized, transferability is the point at which readers can generalize the findings of a study in their own context. The next step was data display, which was done through graphic organizers such as matrixes or tables, for the viewer to give his conclusion. In this step, I read my data several times and came up with several themes, but these themes were narrowed down with the help of my data analyst. Finally, as part of the qualitative analysis, the conclusion was completed. This entailed revisiting the data being analyzed several times in order to accurately see the validity of the conclusion that emerged. The occurrence of conceptual categories and descriptive themes was used to converse the data. Themes were then crafted into which the components were interconnected (Atkinsol \& Delamont, 2006). Then I construed the conceptual structure to the related literature of the phenomenon being studied.

\section{$4.2 R Q$ 1: What are the Revealing Perspectives of Filipino Learners on the Stories of the Holocaust?}

The revealing perspective of the Filipino learners on the stories of the holocaust are fear to fight, feeling of hatred to the oppressors, bravery leads to survival, admiration to survivors of holocaust, condemnation of oppressors' acts, and extending hands to the needy. The participants unconventionally recounted during the interview their thoughts and ideas on stories of holocaust. Table 1 of research question number 1 indicates the six (6) transpiring themes and supporting statements. Table 2 shows the different revealing perspectives of the grade 11 Filipino Learners on the stories of the holocaust.

Table 2

Revealing Perspective of the Filipino Learners on the Stories of Holocaust

\begin{tabular}{|c|c|}
\hline Major themes & Core ideas \\
\hline Fear to Fight & $\begin{array}{l}\text { The holocaust revealed the other side of the European people like they are afraid } \\
\text { to fight. }\end{array}$ \\
\hline & $\begin{array}{l}\text { I believe the Europeans wanted to fight, but their desire was defeated by their } \\
\text { fear. }\end{array}$ \\
\hline & The fact that other European countries fear Hitler made me disappointed. \\
\hline & $\begin{array}{l}\text { I thought Europeans were brave and dignified but, they were as afraid as my } \\
\text { ancestors were during the Spanish colonization. }\end{array}$ \\
\hline & Europeans are cowardly for being afraid of Hitler. \\
\hline Feeling of Hatred to the Oppressors & I hate Hitler for ordering to kill the Jews. \\
\hline & I hate Hitler for that decision to kill the Jews. \\
\hline & I hate Hitler for his inhuman decision to kill the Jews. \\
\hline & I hate Hitler, and it will never change. \\
\hline & I am mad at Hitler for killing the Jews. \\
\hline \multirow[t]{5}{*}{ Bravery Leads to Survival } & $\begin{array}{l}\text { The Jews were strong, and they managed to survive, moved on, and became } \\
\text { stronger. }\end{array}$ \\
\hline & The Jews have become stronger and braver to fight for their rights. \\
\hline & $\begin{array}{l}\text { They were killed in millions, but they managed to go on with their lives and } \\
\text { moved on. }\end{array}$ \\
\hline & The Jews are strong because they moved on, and they started all over again. \\
\hline & $\begin{array}{l}\text { The Jews are brave because some of them managed to survive during the war. } \\
\text { They are brave because they survived. }\end{array}$ \\
\hline
\end{tabular}




\begin{tabular}{ll}
\hline Admiration to Survivors of Holocaust & I love the Jews; they are grateful people. \\
The Jews are admirable for having moved on, and they have forgiven their \\
oppressors. \\
They are grateful people because they constructed a monument in remembrance \\
of our rescue. \\
I pity them, but now I admire them for having moved on from their horrible past. \\
The Jews are living independently and progressively today. They have used their \\
past positively. \\
The Jews are admirable because they did not detain themselves from the past. \\
Every country in the world should learn lessons from the Jews \\
They might be pitiful, but they lead positive lives \\
They are admirable because they picked up the pieces, and they moved forward. \\
The Europeans who murdered the Jews were heartless. \\
I detest Hitler to the highest level. He is the highest form of evil in humans. \\
I despise Hitler so much. Six million life sentences is not enough to free him \\
from his spiritual obligation. \\
Hitler is an evil disguised as a human. \\
Hitler is the worst world leader. \\
Hitler's order to kill the Jews is the highest form of evil. \\
I detest Hitler, and I want to punch him on the face. \\
Hitler is synonymous with evil. \\
Hitler is wicked and has no mercy. \\
Despite knowing the consequences of helping the Jews, our fellow Filipinos still \\
opened the doors for the Jews. Filipinos are great people. \\
I am giving my salute to the Filipinos who worked to rescue the Jews. \\
Filipinos are great people; they made a sacrifice when they welcomed the Jews. \\
The Filipinos who worked on the rescue are commendable. \\
I respect and honor the Filipinos who worked to rescue the Jews. They changed \\
the course of history. \\
Rescuing the Jews made us known to some countries, and they admired us for \\
this action.
\end{tabular}

Fear to Fight - Fear is present in everyone, but you just need to recognize it properly. The participants felt the tremendous fear of the survivors of holocaust based on their revelations and shared perspectives on the stories of the holocaust. It is noteworthy as it has been one of the revealing themes in research question number one (1). The ability of the holocaust survivors and their families to move on to live fulfilling and meaningful life despite the hardships they have faced is a testament to the resiliency of the human spirit. However, the past and present are intermingled. The fear to fight was manifest, after all, human's simplest and most basic need is survival. Below are the shared responses of the participants that transpired during the conduct of study.

"Pinapakita ng holocaust ang ibang katangian ng mga European. Takot silang lumaban. Napansin ko na maraming Jews sa halos lahat ng parte ng Europa pero walang naglakas loob na banggain si Hitler. Siguro nga powerful talaga siya, pero sana may ginawa sila." (FGD-Res. No. 13)

(The holocaust revealed the other side of European people like they are afraid to fight. I observed that Jews are in almost every country in Europe, but none of these European nations dared to go against Hitler. Maybe he was powerful back then, but still, the people should have done something)

Queen (pseudonym) shared and felt confused as she considered Jews to be of great number and can be found in most European countries, but then had not attempted to fight against the oppression of Hitler. Queen, who had not lived through Hitler's desperate times, had expressed fear among Jews because of what had happened in the past and the fact that Hitler was such a powerful person.

"Sa paniniwala ko gustong lumaban ng mga Europeans pero yung kagustuhan nilang lumaban ay tinalo ng kanilang takot. Takot sila na baka mamatay din sila kaya kahit nakikita nila ang lahat nanahimik na lang sila." (IDI- Res. No. 008) 
(I believe that the Europeans wanted to fight, but their desire was defeated by their fear. They were afraid that they would also get killed. So, they remained silent, or they watched in silence.)

Moreover, Pouty (pseudonym) shared that Europeans wanted to fight and survive, but fear succumbed to most of them and isolated them in silence.

"Ang ibang mga Europeans ay duwag din pala. Hindi rin pala nila kayang tumayo sa kanilang mga sariling paa. Hinayaan nilang pagmalupitan sila ng iisang taong malupit” FGD-Res. No. 014)

(Some Europeans are cowardly; they cannot stand on their feet alone. They let one-man rule over them in utmost cruelty)

Petite (pseudonym) added, "Some Europeans are cowards and afraid to stand up for their rights to live and survive."

"Mahal ko ang Europe, lalong lalo na ang Paris. Pangarap kong makapunta doon dahil sa sobrang ganda daw ng Paris hindi daw sinira ni Hitler. Unfair yata, bakit yung iba sinira. Nakaka disappoint yung mga Europeans na natakot kay Hitler.” (FGD-Res. NO. 018)

(I love Europe, especially Paris. I dream of going there someday, and I heard that because of its beauty Hitler could not afford to destroy it. So, Paris was spared, but the fact that most cities are ruined is unfair. The fact also that other European countries feared Hitler made me disappointed.)

Furthermore, Player (pseudonym) shared how she admired Europe and specifically mentioned how she loved Paris and dreamt of someday going there, and for her, the fear of the Jews disappointed her. This admiration for Paris was also noted by Softy (pseudonym) and revealed her disappointment with Europeans. Softy (pseudonym) thought they were brave and dignified. Below are the exact words shared by Softy.

"Nakakadisappoint naman ang mga Europeans, akala ko matatapang sila. Pero para lang pala silang mga ninuno natin noong panahon ng Kastila. "(IDI-Res. No. 009)

(I got disappointed with the Europeans. I thought they were brave and dignified, but they were as afraid as our ancestors were during the Spanish colonization of the Philippines.)

Softy (pseudonym) shared a feeling of disappointment towards the Europeans for their lack of courage compared to the Filipinos during the Spanish colonization.

"Hindi naman pala ganun kalakas ang mga European countries. Sabi nil amalakas at maunlad sila. Kung totoo di sana di sila katulad natin na takot. Pero takot sila kay Hitler” (FGD-Res. No. 016)

(The European countries are not that great after all. If they claim to be a rapidly growing nation, they must be more dignified than third-world countries. But as it turned out, Europeans are cowardly for being afraid of Hitler.)

Techy (pseudonym) then added and shared those European countries are not so great after all, belonging to the first world countries and even compared them to the third world countries that even as such, turned out to be more dignified as some third world countries were familiar with revolts in oppression.

Feeling of Hatred to the Oppressors - The second emerging theme revealed in the study was the feeling of hatred toward the oppressors. Having a sense of purpose is vital to creating meaning in one's life. This is especially true for resilient survivors of traumatic events like the holocaust. But, how can one find the fundamental purpose in life when the fear succumbs, and feeling of hatred grows? Below are the shared ideas of 
Escalante, L., \& Gomez, D.

participants in the second emerging theme.

Ang mga Europeans na pumatay sa mga Jews ay malulupit, walang puso. Galit din ako kay Hitler kasi pinapatay niya ang mga Jews. Sana pinatay din siya gaya ng pagpatay niya sa mga Jews." (FGD-Res. No. 020 No.)

(The Europeans who murdered the Jews are cruel and heartless. I also hate Hitler for ordering to kill the Jews. He should have been killed the way he killed the Jews.)

Innocent (pseudonym) shared her feelings of hate towards the oppressors. She was firmly harsh to utter hateful words towards the oppressors. Moreover, Shy (pseudonym) shared her anguish too towards Hitler for his decisions, and firmly believed that what Hitler had done was cruel and wicked. Below are the exact words of Shy.

“Galit ako kay Hitler kasi pinatay niya ang mga Jews. Para naman siyang Dios upang magdesisiyon kung sino ang mamatay at hindi. Siya ang pinakamasamang lider sa buong mundo. Iyan ang nasa isip ko" (IDI-Res.No. 003)

(I hate Hitler for that decision to kill the Jews. He seemed like God who decides who lives and who dies. He is the worst leader ever in history. That is my stand)

Brunette (pseudonym) further added,

Sobrang galit na galit ako kay Hitler. Hindi ko maintindihan bakit pa siya nabuhay kasama ng tao. Dapat bago siya maging lider sana ipakita niyang tao siya. hindi yung para siyang hayop na galit." (IDI-Res.No..001)

(I hate Hitler to the highest level. I do not understand why a person like him should live and mingle with people. He should at least be a person to become a leader and not like an angry animal)

Additionally, Brunette (pseudonym) shared her grief and revealed repulsive words towards Hitler.

“Galit ako kay Hitler sa pagpatay niya sa mga Jews. “(FGD-Res. No.015)

(I hate Hitler for killing the Jews.)

Bravery Leads to Survival - Another emerging theme is bravery leads to survival. Bravery is what made us overcome fear and trepidation. We live accordingly to deeply ingrained patterns. The survival stories of the holocaust inspire courage and the will to go on. Below are the responses shared by the participants on this theme.

Long Legs (pseudonym) shared his thoughts regarding the bravery of Jews that leads to survival and eventually, in the present days, they evolved as one of the greatest nations in the world. Below are his shared ideas on bravery of Jews which leads to survival.

"Matibay ang mga Jews. Ang kanilang pinagdaanan ay isang bangungot pero nakayanana nilang ipagpatuloy ang buhay. Ang Israel ngayon ay isang malakas na bansa at halos nasakop na niya lahat ng teritoryo sa kanyang mga borders.' (IDI-Res. No.006)

(The Jews are strong. Their past is a nightmarish one, but they managed to move on and become stronger. Israel now is undefeated, and it has occupied most of the surrounding its location.)

Slender (pseudonym) also shared that the affliction towards the Jews had made the Jews stronger, as it is evident at present times.

"Natalo man ang mga Jews noon pero panalo na sila ngayon. Naging malakas sila at kaya na 
nilang lumaban. “(FGD-Res.No.015)

(The Jews may be losers in the past, but they emerged victorious today. They have become stronger and braver to fight for their rights.)

Petite (pseudonym) shared her thoughts that Jews had suffered much more than anyone in the world and that despite everything that happened, they have moved on and turned out to be fantastic people.

Sa lahat ng tao sa tigin ko ang mga Jews ang nakaranas ng pinaka kahindik hindik na racial discrimination dahil milyon milyon silang pinatay. Pero nakaya nilang mag move on. Nakakabilib naman sila," (FGD-Res. No.14)

(Of all the races, I guess the Jews suffered the most horrible racial discrimination because they were killed in millions, but they managed to go on with their lives and moved on. They are amazing people.)

Writer (pseudonym) shared that what happened to Jews in the past had become a steppingstone of learning from the awful things that happened to them.

"Malakas ang mga Jews kasi naka move on sila at nagawang magsimulang muli. Ginawa nilang inspirasyon ang kanilang past para magpatuloy." (FGD-Res. No.019)

(The Jews are strong because they moved on and started all over again, taking every lesson of the past as an inspiration to move forward.)

Tall (pseudonym) stressed the survival of Jews only shows they were brave and courageous.

"Matatapang sila dahil ang iba sa kanila ay nakaligtas noong kasagsagan ng giyera. Sa kabila ng pait ng nakaraan nagawa nilang mag move on." (IDI_res.No.012)

"They are brave because some of them managed to survive during the war. Despite the pain of the past, they moved on."

Skinny also shared that the Jews' bravery made it possible for them to survive.

"Matapang sila kasi yung iba sa kanila nakasurvive. Hindi naman nila ginustong maging biktima sadyang mapait na kapalaran lang talaga ang nangyari sa kanila."(IDI-Res.No.002)

(The Jews were brave. Some of them survived. They did not choose to be victims, but it was a sad fate befallen them)

Moreover, the participants shared the bravery of Jews. Fear is closely linked to survival. In the face of great adversity, the Jews have shown time and again that they have the determination and courage to do what it takes to survive and live life to the fullest.

Admiration to Survivors of Holocaust - Another emerging theme is admiration to survivors of holocaust. Queen (pseudonym) shared her great admiration towards the survivors. Her adoration for Jews surviving the holocaust was evident on her words below written:

Kaibig-ibig ang mga Jews dahil sa kabila ng kanilang kahindik hindik na nakaraan nagwa nilang lumimot at mabuhay nang marangal. Bumuo sila ng sariling bansa at tumanaw ng utang na loob sa mga taong nakatu;long sa kanila. They are great people. (FGD-Res. No.013)

(I love the Jews because despite their horrible past, they managed to move on, and they lived with dignity. They established their own country, and they look back to the people who helped them. They are grateful people.) 
Escalante, L., \& Gomez, D.

Pouty (pseudonym) added that the Jews are commendable despite all the affliction, they survived and moved on.

“Kahanga-hanga ang mga Jews dahil naka moved on sila pagkatapos ng holocaust. Nakaya nilang kalimutan ang isang brutal at walang kasing samang buhay. Siguro hindi pa nila napatawad ang mga Germans pero civil silang tao, hindi mapaghiganti.” (IDI-Res. No 008)

(The Jews are admirable for having moved on after the holocaust. It was a tormenting and devastating past, but they learned to forget. I am not sure if they have forgiven the Germans, but I see they are civilized people.)

Besides, Innocent (pseudonym) shared that Europeans turned out to be far richer than us and were grateful to the Philippines as they constructed a monument to welcome them as refugees to our country.

"Hindi na sila kaawa-awa ngayon. Sa totoo lang mas mayaman pa sila sa atin. Pero marunong silang tumanaw ng utang na loob kasi nagpapagawa sila ng monyumento bilang pag alala sa pag rescue natin sa kanila." (FGD-Res.No.020)

(The Jews are pitiful no more. They are far richer than us. They are also grateful because they have constructed a monument in remembrance of our rescue.)

Moreover, Softy (pseudonym) shared how she admired the Jews who survived and moved on and lived an independent and progressive life.

"Naaawa pa rin ako sa kanila kasi grabeng kawawa sila. Perookay na sila ngayon kasi naka move on na sila." ((IDI-Res. No.009)

(I still pity them because they suffered so much, but I admire them now because they have moved on.)

This was supported by Techy (pseudonym) when he expressed:

"Ang mga Jews ngayon ay nabubuhay na nang matiwasay at maunlad. Pwede nating sabihin na may natutunan sila sa nakaraan. Ginamit nilang inspirasyon ang nakaraan para maka move on. " (FGD-Res.No.016)

(The Jews today are living independently and progressively. So, we can say that they have learned their lessons well. They might be pitiful, but that was in the past. They have used their past positively to move forward.)

Happy (pseudonym) added how she admired the Jews who survived the darkest days of their lives, which simply stresses the idea that there is a light at the end of a tunnel.

“Ang mga Jews ay kahanga hangang lahi dahil nagawa nilang lumimot sa kanilang kahindik hindik na nkaraan. Hindi nila ikinulong ang kanilang mga sarili sa nakaraan bagkus ginamit nila ito upang umunlad. (IDI-Res.No.007)

(The Jews are admirable people because they moved forward despite their dark and horrible past. They did not detain themselves with the past, but they used it to improve their lives.)

Moreover, Leader (pseudonym) shared how they admired the Jews and thought that Jews should be a role model for withstanding great obstacles in their lives and now stood solid.

"Sa tingin ko dapat lahat ng bansa dapat matuto sa kuwento ng mg Jews kasi nagawa nilang mag move on at ngayon is ana sila sa pinaka powerful na country sa buong mundo." (IDI-Res. 
No. 005)

(I guess every country I the world should learn lessons from the Jews. They have learned to move forward despite the pain and trauma. Today, they are one of the most powerful countries in the Middle East.)

Furthermore, Artist (pseudonym) shared how they were so helpless and that everyone can learn from their experience and always embrace positivity in life.

"Kaawa-awa sila pero hindi naman lubusang kaawa-awa kasi nagwa nilang magsimulang muli. Natuto sila at nagsumikap na maakaroon ng magandang buhay.” (IDI-Res.No.004)

(They may be pitiful, but they are not helpless. They moved forward and picked up the pieces. They learned from their experience, and they tried to lead positive lives.)

Pretty (pseudonym) also shared her view that Jews remained kind and amazing people and continued to live without hatred towards the Germans, as it was only on Germany to persecute the Jews.

"They are all so pitiful. Pero amazing din sila kasi naka move on sila. Ang hirap maniwalang kaya nilang mabuhay na hindi namumuhi sa mga Germans. Sabi nila kalimutan na ang nakaraan pero dapat matuto tayo, upang pagdating ng panahon marunong tayong lumaban at huwag hayaang mangyari ang kagimbal-gimbal na pangyayaring tulad nito." (IDI-Res.No. 011)

(They are all so pitiful. However, they are also amazing people for having moved on forward. I cannot believe they can live without hating the Germans. We must not dwell on the past, they say but, it is vitally important that we learned, so that in our turn we will stand up and not let such atrocities happen.)

Moreover, Shy (pseudonym) shared how sorry she is for the Jews who lost their parents and families but admired their strength to survive and to move on and live an independent and progressive life.

"Nakakalungkot na ang iba sa kanila ay hindi na muling nakita ang mga magulang. nandun yung sakit na umaasa kang isang araw makikita mo ulit sila pero wala na. nakakabaliw yun pero grabe sila nakaya nilang kalimutan yun at magsimulang muli." (IDI-Res.No.003)

(It was heartbreaking that some of them did not get to meet their father or mother again. They bear the pain of hoping to see their family again only to find out that they are gone. That was distorting. But they tried to forget all these and started anew.)

Furthermore, most participants shared admiration for people who performed heroic acts during times of turmoil and oppression.

Condemnation of the Oppressors Acts - Another theme presented in this study was the condemnation of the oppressor's acts. Unjust treatment and abuse of power have never been good for people. Oppression is madness, and no person in the good sense of mind can dare do such, but many wicked people who were hungry for power and only torture and oppression are known to them. Below are the shared thoughts and ideas of the participants on the mentioned theme.

Innocent (pseudonym) expressed frustration and anger toward the oppressors, believing that their hearts were hollow, and that life had no value.

“Ang mga Europeans na pumatay sa mga Jews ay walang mga puso.” (FGD-Res.No.020)

(The Europeans who murdered the Jews are heartless) 
Escalante, L., \& Gomez, D.

Artist (pseudonym) also reiterated her hatred towards the actions of the oppressors and stated:

"Ang ginawa ng mga Nazi sa mga Jews ay walang kasing sama kaya ako nagagalit sa kanila. Akala ko pa naman marangal silang mga tao kasi mayaman silang bansa.” (IDI-Res.No.004)

(What the Nazi did to the Jews are horrible, and so I got mad at them. And I was disillusioned because I thought highly of them because they are giant economies.)

Extreme hatred towards the oppressors was also evident based on Queen's (pseudonym) reply to the questions thrown at her.

“Kinamumuhian ko si Hitler nang sobra sobra. Dapat mamatay siya sa pamamagitan ng pagpugot ng kanyang ulo or kahit mas malupit pa dahil sa pagpatay niya sa mga Jews. Siya ang pinakamasama sa lahat ng taong masama." ((FGD-Res.No. 013)

(I detest Hitler to the highest level. He deserved to die in a guillotine or even worse than that for claiming millions of lives. He is the highest form of evil in Humans.)

After knowing the stories of holocaust, Long Legs also expressed feelings of anger and frustration on how the oppressors acted.

"Kinamumuhian ko siya. Kahit pa mamatay siya ng 6 milion times hindi sapat yun upang nakalaya siya sa kanyang spiritual na kaligtasan. Hindi niya dapat ginawa yun." (IDI-Res. No.006)

(I despise him so much. Six million life sentences is not enough to free him of his spiritual obligation. He should have never done that.)

Extending Hands to the Needy - The next emerging theme discussed is extending hands to the needy. It is true indeed that in great turmoil and suffering come helping hands ready to help. In times during the holocaust, Jews were welcomed by the Filipinos to be refugees.

Queen (pseudonym) shared the above statement that Filipinos who welcomed the survivors of holocaust were heroic acts. The Philippines, over the years, have always been about "bayanihan" spirit. The hospitality of the Filipinos has always been the reaching hands that extend help to the needy.

"Noong pinagbuksan natin ng pintuan ang mga Jews alam nating madadamay tayo kung sakaling magalit si Hitler. Pero pinatuloy pa rin sila ng mga kapwa nating Pilipino, so iisa lang ang ibig sabihin nito, bayani rin ang mga kapwa Filipino dahil ang kanilang ginawang ay isang kabayanihan." (FGD-Res. No.013)

(When we opened our doors to the Jews, we knew the consequences that we had to suffer if Hitler made a move. However, our people still welcomed the Jews, so it only means one thing. They are heroes because what they did is a heroic act.")

Moreover, Slender shared how the Filipinos are helpful and mindful of the Jews and had shown selflessness in helping save their lives.

"Mabubuting tao ang mga Filipino dahil nagbuwis sila ng buhay nang patuluyin nila ang mga Jews. Makapangyarihan si Hitler at takot ang lahat sa kanya.” (FGD-Res.No.015)

(Filipinos are good people, they made a sacrifice when they welcomed the Jews because they knew they would be risking their lives. Hitler was a powerful man, and everyone was afraid of him.)

214 Consortia Academia Publishing (A partner of Network of Professional Researchers and Educators) 
Player (pseudonym) shared how the Filipinos are generous and thoughtful of the Jews and had shown sincerest kindness in helping save lives. Filipinos, after all, are hospitable and accommodating, giving to those in need without expecting anything in return.

"Ang mga Pilipinong tumulong sa mga Jews ay dapat parangalan. Hindi lang ang kanilang bansa ang inialay kundi pati na rin ang kanilang mga sarili. Nagpakita sila ng halimbawa ng pagbibigay na hindi naghihintay ng kapalit.” (FGD-Res.No.018)

(The Filipinos who worked on the rescue were commendable for their deeds. They shared not only their country but also themselves. They have manifested the utmost way of giving without counting the cost.)

Moreover, Petite (pseudonym) shared how he is proud of the Filipinos for helping shape the future of the Jews during these trying times.

"Ikinararangal at iginagalang ko ang mga Pilipino dahil iniba nila ang kasaysayan ng mundo. Ang isang maliit at hindi kilalang nasa sa Asia ay may ginawang kakaiba sa kasaysayan ng mundo." (FGD-Res. No.014)

(I respect and honor The Filipinos for having changed the course of History. A small and unknown country in Asia has made the difference.)

Furthermore, Writer (pseudonym) compared this massive act done by the Filipinos towards Jews, that of Manny Pacquiao in his greatness. The help offered by the Filipinos towards Jews was so great that it made it possible to help change the course of fate for many. This made the Filipinos hospitality and kindness around the world, as stated below.

“Ang pag rescue sa mga Jew ang isa sa pinakamalaking pangyayari sa ating bansa sunod kay

Manny Pacquiao dahil nakilala tayo sa maraming bansa. (FGD-Res.No. 019)

(The biggest thing that happened to the Philippines next to Manny Pacquiao is rescuing the Jews.

It made us known to some countries.)

\subsection{RQ 2: How Learners Relate the Stories to the Social Issues at Present?}

Thoughts and ideas of how learners relate the stories to the social issues at present are disclosed in the following themes: the holocaust is far from reality to happen again, racial discrimination, and image of a hero. Table 3 presents how learners relate the stories of the holocaust to the social issues at present.

\section{Table 3}

How Learners Relate to the Stories to the Social Issues at Present

\begin{tabular}{cl}
\hline Major themes & \multicolumn{1}{c}{ Core ideas } \\
\hline again & Because of the rise of information and communications technology, everything is \\
shared around the world, so if there was another holocaust, it would be stopped \\
immediately. This is a common misunderstanding. \\
I do not think there would be another holocaust because every country in the \\
world is already connected on the net. It is challenging to stage another one \\
because the world will be watching. \\
If there are still countries where the holocaust is likely to happen, people can get \\
help from international human rights sites. \\
I do not think another holocaust will succeed because of today's open \\
communication system. \\
I believe that it is already challenging to stage a holocaust today because we \\
already have access to information technology, countries will be helping one \\
another. \\
I do not think another holocaust will happen because everyone is updated now. \\
I do not think the holocaust will become successful; every nation is updated.
\end{tabular}


Racial Discrimination

Image of a Hero
Today everything can be solved with proper communication, so I guess there is no way another holocaust will prosper.

I do not believe that a holocaust will succeed today; through social media, everything is divulged.

ICT is a breakthrough; everyone is connected, so I do not think another holocaust will happen.

I cannot think that another holocaust will happen, not only because everyone is connected but I believe that we learned from the past.

We think that racial discrimination is over, but it is not. Even in our own country, we still discriminate but not as brutal as the Germans.

I realized that racial discrimination damaged the Jews, not only their lives but their dignity as people.

Because of the holocaust and racial discrimination, I realized how pitiful are the Jews.

The holocaust minced the Jews, they lost everything, and it all started with racial discrimination.

After the holocaust I realized that the discrimination of the Jews that led to the holocaust is the cruelest form of racial discrimination worldwide.

I realized that racial discrimination could never be eradicated.

I realized that we should not discriminate against other people because it may lead them to death.

Small- or big-time discrimination is still discrimination, So I learned that we should never discriminate because it is highly inhumane to do it.

We should not discriminate because we hurt the feelings of others that will traumatize them in their whole life.

We should not discriminate because our simple act of discrimination could change lives and even kill the people being discriminated.

Racial discrimination is common but is a susceptible issue. One discrimination may lead to another that might lead all victims to their graves.

Racial discrimination can kill thousands of people; it is sensitive and damaging.

When we discriminate against people, we judge and persecute them, we are doing them an injustice.

I realized that racial discrimination is still happening today. There are still those who are being discriminated against by their own people.

The Jews died because they were discriminated against. If Hitler did not discriminate against them, there would be no holocaust in world history. I realized how pitiful the Jews were because they were being discriminated against.

Even in countries where there is equality, racial discrimination is still present. S I guess discrimination can be reduced but can never be eliminated.

Because of this act of heroism, we are considered heroes by the Jews that we saved, and it made me proud as a Filipino.

For saving the Jews, we have come to be known as a small country with a big heart, and I felt proud.

After the rescue of the Jews was published online through YouTube, I feel proud as a Filipino.

We have come to prove once again that Filipinos are dignified people.

Filipinos are proud of the great deeds of our ancestors, especially our former President Manuel L. Roxas.

Because of the incredible rescue, the Philippines and Israel become allies. Filipinos become more confident because they learn that they came from an ancestry that is humane and dignified.

We were able to show the world that we have the will to do what is right in critical situations like saving the Jews and going against Hitler.

The Jews become our allies, and we can visit their country any time visa-free. We have gained worldwide popularity as the small country in Southeast Asia who open the door to those who need it.

We gained an ally that look up at us with a grateful heart.

Netizens recognized Filipinos as dignified people.

Opening our doors to the Jews when everyone else is closing theirs has given us a trademark of being good-hearted.

People look at Filipinos as good people.

Holocaust is Far from Reality to Happen Again - Statement shared by Queen (pseudonym) is optimistic, that holocaust is far from reality to happen again because of the new information technology era. Her words are: 
"Dahil sa paglaganap ng ICT, madali na lang mag share ng information, Hindi lang balita ang pwedeng I share pati na rin mga updates sa iba't ibang bansa. Kaya kung meron mang nabubuong holocaust, malalaman na ito ng mga tao bago pa masimulan." (FGD-Res. No.013)

(Because of the rise of Information and Communications Technology, sharing of information has become more accessible. Not only is news shared, but so are updates and situations in every country. So, if there would be another holocaust, it will be stopped before it begins)

Long Legs (pseudonym) agreed as well that this is far from happening again. She shared below, the world would be watching, and it would be difficult for another holocaust ever to happen again:

"Sa tingin ko wala ng holocaust na mangyayari dahil konektado na sa internet ang lahat ng bansa sa mundo. At kung may holocaust man ulit hindi na siguro ganun kadami ang victims. Ang mga taong gagawa nito ay magdadalawang isip din dahil nakatutok ang buong mundo.' (IDI-Res.No.006)

(I do not think there would still be another holocaust because every country in the world is already connected on the net. However, If there is another holocaust, there will be a lesser number of victims. Moreover, the persons who will be doing it will think more because they know it will be difficult because the whole world will be watching.)

Moreover, Slender mentioned that people all around the globe can get help from International Human Rights.

"Kung may mga bansa man sa mundo na pwedeng magkaroon ng holocaust, pwede nang humingi ang mga tao ng tulong sa Human Rights sites. Magiging controversial ito at maaring pagmualan ng isa na namang world war, hindi katulad noon kasali sa giyera. Buong mundo na ang makakalaban ng mga gagawa ng holocaust." FGD-Res. No.015)

(If there are still countries in the world where the holocaust is likely to happen, people can get help from International Human Rights sites. It will be sensationalized, and start a world war, unlike before that it was embodied in a war. I think the world will revolt against the perpetrators.)

Furthermore, Pouty (pseudonym) emphasizes the influence the internet can do especially with the different platforms of social media circulating all around the globe, would have helped a piece of instant information for everyone.

"Dahil sa malawakang paggamit ng internet at multimedia, malabong hindi natain malalaman ang mga nangyayari sa isang bansa.Sa tingin ko Malabo nang magka holocaust uli” (IDI-Res. No. 008)

(With the increasing usage of multimedia and the internet, there is no way people from other countries would not know about what is happening in a certain country. I do not think there will be another holocaust)

Moreover, Player (pseudonym) mentioned WWW or the worldwide web as everyone can get connected as easily as 1-2-3. Through the world wide web, news and information are easily and readily be sent in an instant.

"Dahil sa world wide web, makakapagligtas tayo ng mas maraming tao. Kung I news balack out man nila, marami ng hackers na pwedeng maka access. May nabasa nga akong liny ana wala na daw secret ngayon." (FGD-Res.No.018)

(Through the world wide web we can save more people. Although authorities in a certain country would implement news blackout, hackers will find a way to spread the news. As one of the lines 
Escalante, L., \& Gomez, D.

that I read, nothing is secret anymore.)

Tall (pseudonym) also mentioned of the holocaust might not be happening again, with her statement contradicting the saying, "History repeats itself".

“Wala na sigurong mangyayaring holocaust dahil updated na lahat eh. Kung sakali man hindi na ito sa pagitan ng mga Nazi at mga Jews. Natuto na ang mga ito at hindi rin naman siguro nila I repeat ang history." (IDI-Res. No.012)

(I do not think another holocaust will happen because everyone is updated now. However, just in case there would be another one, it will no longer be between the Jews and the Nazis. These two people have already learned from it, and they are not likely to repeat history.)

Leader (pseudonym) also shared the same thoughts that communication in the new era plays a vital role in divulging plots and plans such as the holocaust.

"Hindi ako naniniwala na magtatagumpay ang anumang holocaust sa panahon natin ngayon kasi nakikita na lahat sa social media eh.” (IDI-Res. No. 005)

(I do not believe that a holocaust will succeed today. Through social media, everything is divulged.)

Racial Discrimination - Another emerging theme for research question number 2 is racial discrimination. Below are the shared ideas of participants on this theme. Loop shared about racial discrimination from the holocaust.

"Natuto na siguro tayong lahat sa holocaust. Pero kung akala natin na tapos na ang racial discrimination, sa tingin ko hindi pa dahil kahit sa ating sariling bansa we are discriminating people." (FGD-Res.No.013)

(I believe that everyone learned from the holocaust. We think that racial discrimination is over, but it is not. Even in our own country, we still discriminate but not as brutal as the Germans)

Long legs (pseudonym) also shared how racial discrimination destroyed the lives of Jews and that everyone should learn from it.

"I realized na nasira ng racial discrimination ang buhay ng mga Jews pati ang kanilang dignidad. Maraming taon ang lumipas bago sila nakalimot sa trauma ng nakaraan." (IDI-Res. No. 006)

(I realized that racial discrimination damaged the Jews, not only their lives but their dignity as people. Moreover, it took them years before they finally moved on from the trauma that they were in.)

Slender also shared how racial discrimination destroyed the lives of Jews and that everyone should learn from it.

"Dahil sa racial discriminationat holocaust narealize ko na sobrang kawawa pala ang mga Jews. Sana matuto tayong lahat laong lalo na ang mga kabataan na magiging pinuno natin sa hinaharap." (FGD-Res. No. 15)

(Because of the holocaust and racial discrimination, I realized how pitiful the Jews were. Everyone should learn from it, especially the young people today who will be leading us in the future.)

Pouty (pseudonym) also shared how the holocaust broke the Jews into pieces and how they have lost 
everything.

"Grabe ang holocaust parang tinadtad nang pinung-pino ang mga Jews. Nawala ang lahat sa kanila at itoy nagsimula sa racial discrimination.” (IDI-Res.No.008)

"The holocaust minced the Jews, and they lost everything, and it all started with racial discrimination." (Pouty)

Player shared how the people and the citizen of the world can work to stop racial discrimination.

"Pagkatapos ng holocaust narealized ko na ang racial discrimination na nangyari sa mga Jews ang pinakamalupit sa buong mundo. Itong kahindik hindik na bahagi ng kasaysayan ng mundo ay isang katotohanang hindi natin masyadong sinseryoso kasi iniisip natin na nangyari ang lahat dahil siguro iyon ang dapat. Sana lang lahat ng bansa ay alagaan ang kanyang mga mamamayan para wala ng mangyayari pang ganito." (FGD-Res No.018)

(After the holocaust I realized that the discrimination of the Jews that led to the holocaust is the cruelest form of racial discrimination worldwide. That sad and horrible part of world history is a truth that we do not always see or a truth that we think just happened because it is bound to happen. Every country in the world should take care of its citizen so there will never be another holocaust.)

Techy (pseudonym) also shared her thought on racial discrimination, and what damages it can do to the lives of many people.

"Huwag tayong magdiscriminate dahil yung simpleng discrimination na ginagawa natin ay maaaring ikamatay ng tao." (FGD-Res.No.016)

(We should not discriminate because our simple discriminating act could change lives or even could lead people to their death like the Jews)

Image of a Hero - Another emerging theme is Image of a hero. The participants expressed their thoughts related to this theme. One participant, Loop, made mention how the sacrifices of our countrymen has made the Filipinos proud:

"Dahil sa kabayanihang ginawa ng ating mga kababayan tinanghal tayong bayani ng mga Jews.Nakakaproud maging Pilipino. Hanggang ngayon,tinatanaw ito ng mga Jew kaya pag pupunta tayo ng Israel hindi na kailangn ang visa." (FGD-Res.No.013)

(Because of this act of heroism, we are considered heroes by the Jews that we saved, which made me feel proud as a Filipino. Even today, the Jews recognized such action by allowing us to go to their country without a visa.)

In addition, Long Legs (pseudonym) also verbalized how our country was branded as a small nation with a heart.

"Dahil sa pagsagip natin sa mga Jews nakilala tayong maliit na bansa na may malaking puso. Nakakaproud." (IDI-Res.No.006)

(For saving the Jews, we have come to be known as a small country with a big heart and, I feel proud.)

Also, Slender (pseudonym) linked a movie related to the holocaust and cited how it is an eye opener for Filipinos:

“Ang pelikulang “Quezon's game” ay isang eye opener.Kung nagawa ng isang third world 
Escalante, L., \& Gomez, D.

country bakit hindi kaya ng mas malalaking bansa? Plus na yung relationship natin with Israel naging mas mabuti. (FGD-Res. No.015)

(The movie Quezon's Game is an eye-opener. If a $3^{\text {rd }}$ world country can do it, why can't big countries do it? Plus, the relationship between the Philippines and Israel has become better.)

Pouty (pseudonym) also stated how proud he has become after watching stories of Holocaust in YouTube:

"Nung maanood ko sa YouTube ang pagrescue natin sa mga Jews, proud ako na Pilipino ako. Hindi man tayo mayaman pero tong ginawa natin hindi kayang pantayan ng ibang bansa. Tapos nagrant pa tayo ng Israel ng free visa, lalong nakaka proud talaga." (IDI-Res.No.008)

(After the rescue of the Jews was posted on YouTube, I feel proud as a Filipino. My country may not be rich, but this is always something I bet no other country will equal. By granting us Filipinos with free visas, we are even prouder of what we did.)

Innocent (pseudonym) commends the great decision made by the former Philippine President, Manuel L. Quezon:

Ang mga Filipino ay sobrang proud sa kabayanihang ginawa ng ating mga ninuno. Ako mismo, kahit student pa lang ako, na amazed ako sa kabayanihang ginawa ni President Quezon." (FGD-Res.No. 020)

(Filipinos are proud of the great deeds of our ancestors. As a young Filipino learner, I am amazed at our former President Manuel L. Quezon)

Softy (pseudonym) reiterated the Filipino spirit to act even in a difficult situation.

"Naipakita natin sa buong mundo ang na kaya nating gumawa ng tama kahit tayo ay nasa kritikal na kondisyon kagaya ng pagsalaungat kay Hitler who is a powerful man.” (IDI-Res. No.009)

(We were able to show to the world that we have the will to do what is right in a critical situation like going against Hitler, who was a powerful man.)

Leader (pseudonym) shared his readings about the monument of open-door concretizing the incredible rescue that we did for the Jews:

"Nakilala tayo bilang isang munting bansa sa South Esat Asia na may bukas na pintuan para sa mga nangangailangan. Kaya itinayo ang monument of Open door sa Israel upang pagtibayin ang katotohanang ito." (IDI-Res. No. 005)

(We have gained a popularity as a small country in South East Asia with Opened Door to those in need. Thus, a monument of open-door was constructed in Israel to concretize this truth)

Brunette (pseudonym) shared that opening our doors we were given the trademark as people with kind heart:

"Dahil pinagbuksan natin ng pintuan ang mga Jews samantalang pinagsasarhan sila ng halos lahat ng bansa, tayo ay kinilala bilang mga taong may mabuting puso. Naipakita natin na tayo ay matulungin." (IDI_Res. No. 001)

(Opening our doors to the Jews when everyone else is closing theirs has given us the trade mark of being good-hearted. We were able to establish a reputation that we are kind.) 
$4.4 R Q 3:$ What are the insights of learners on the stories read?

The insights in the stories that the readers learned were revealed in the following themes: 1) the power of action; 2) the essence of freedom; and 3) sovereignty issues. Table 4 shows the insights of Learners in the stories of Holocaust that they have read.

\section{Table 4}

Insights of Learners in the Stories Read

\begin{tabular}{|c|c|}
\hline Major themes & Core ideas \\
\hline The Power of Action & $\begin{array}{l}\text { I learned that the desire to fight evil should be instilled in every human being so } \\
\text { that no one will ever infringe on our rights again. } \\
\text { I learned that in life, you need to fight to survive. In war, you need to kill to win } \\
\text { We should fight even though we know that the chance to win is slim; if we lose, } \\
\text { at least we tried. } \\
\text { We should learn to fight for ourselves and help those who need our help. } \\
\text { Learn how to fight. Stand without depending on others. }\end{array}$ \\
\hline The Essence of Freedom & $\begin{array}{l}\text { Freedom is not just living in a democratic country; it is living with peace and } \\
\text { dignity. } \\
\text { Freedom is elusive even in other countries. } \\
\text { Freedom is something we need to work on; it is a responsibility. } \\
\text { Freedom is doing things in harmony with the government and all the people in a } \\
\text { particular country. } \\
\text { Freedom is not easily attained; we must endure some sacrifices to attain it. } \\
\text { Freedom is attained through unity. } \\
\text { If there is freedom, we can do everything within the bounds of the law. }\end{array}$ \\
\hline Sovereignty Issues & $\begin{array}{l}\text { During the holocaust only the Germans are sovereign } \\
\text { Sovereignty lies in the hands of the rich and powerful. } \\
\text { Sovereignty and equality are not achieved. } \\
\text { Sovereignty is only for the Nazis; they are sovereign; the Jews are powerless. } \\
\text { Sovereignty should be a power that everyone possess. }\end{array}$ \\
\hline
\end{tabular}

The Power of Action - One of the emerging themes of research question number three is the power of action. The participants shared what are the insights they had learned. The keywords and phrases that are related to the emerging theme "the power of action" were; fight against evil, fight to survive, should fight, fight for ourselves, pray to give us strength, without depending, be compassionate, safeguard our rights and dignity, and to be free we must work on it. Player shared her insights with the stories she has read:

\footnotetext{
"Dapat pala matuto ang lahat ng tao na lumaban sa kasamaan upang hindi tayo tapak-tapakan." (FGD-Res. No.018)
}

(I learned that the will to fight against evil doings should be learned by every human being so that nobody will ever step on our rights again.)

Writer (pseudonym) also expressed her outlook regarding the stories:

"Dapat matuto kang lumaban para mabuhay. Sa giyera dapat makapatay ka para manalo." (FGD-Res. No. 018)

(I learned that in life, one needs to fight to survive. In war, one needs to kill to win.)

Tall also stated the importance of action to win: "Dapat tayong lumaban kahit hindi tayo sigurado kung mananalo tayo ang importante
sinubukan natin." (IDI-Res. No.012)

(We should fight, although we know the chance to win is slim. If we lose at least we tried.)

Skinny (pseudonym) also verbalized the pertinence of action: 
Escalante, L., \& Gomez, D.

"Dapat matuto tayong lumaban para sa ating mga sarili at tulungan ang mga taong nangangailangan ng tulong. " (IDI-Res.No.002)

(We should learn to fight for ourselves and help those who need our help)

Happy (pseudonym) also pointed out the need to stand on one's foot and learn to fight

"Matutong lumaban at tumayo sa sailing mga paa. Huwag umasa sa iba." (IDI-Res.No.007)

(Learn how to fight. Stand without depending on others)

The Essence of Freedom - Another emerging theme is the essence of freedom. Participants shared the insights they have learned, below, is the statement of Queen, who shared thoughts about freedom in its truest sense. Common keywords and phrases that emerged were democratic, peace, dignity, elusive, free from abuse and oppression, and to be responsible for sustaining freedom.

"Ang Kalayaan ay hindi lamang dahil nakatira ka sa isang democratic country kundi pamumuhay na may kapayapaan at pagkakaisa. Kung wala kang kapayapaan at dignidad, hindi ka pa rin malaya." (FGD-Res. No. 013)

(Freedom means not just living in a democratic country but also living with peace and dignity. If we are ripped of peace and dignity, we are not free.)

Slender (pseudonym) also highlighted this outlook and shared how he believes that freedom is elusive.

"I learned that freedom is elusive. Ang ibang bansa ay nagsasabing malaya sila pero nababalitaan natin na may mga taong nakukulong dahil sa kanilang pagsulat $g$ katotohanan laban sa mga kurakot na leadres. Dapat ang freedom ay malaya ka mula sa oppression at pang aabuso." (FGD-Res.No.015)

(I learned that freedom is elusive. Some countries claim that they are free, but we read stories about them being jailed for writing something against corrupt leaders. Freedom is being free from oppression and abuse.)

Pouty (pseudonym) also made mention that:

Kung gusto natin maging malaya, dapat pagsikapan mong maging malaya, dapat ka ring magsakripisyo." (IDI-Res. No. 008)

(I realized that when we want to be free, we have to work on it. We have to sacrifice)

Player further express her outlook about a country's freedom:

“Para sa akin walang bansang totoong malaya.” (FGD-Res.No.018)

(For me, there is no country that is free.)

Petite (pseudonym) voiced out that freedom should be earned:

“Ang Kalayaan ay pinaghihirapan. Hindi ito napupulot kung saan saan lang. Sa paghahanap natin ng Kalayaan dapat responsible tayo upang mapanatili natin ito." (FGD-Res. No.014)

(Freedom is something we need to work. It cannot be picked just anywhere. In our quest for freedom, we need to be responsible to sustain it.)

Writer (pseudonym) on the other hand added that freedom is working in harmony with your government and its people: 
"Na realize ko na hindi lahat ng bansa sa mundo ay malaya. Ang Kalayaan ay hindi lamang pagtira sa isang malayang bansa kundi ito ay Kalayaan na gawin ang mga bagay na may pakikipagtulungan sa pamahalaan at sa mga mamayan.” (FGD-Res. No.019)

(I realized that no country in the world is free. Freedom does not only mean living in a democratic country, but it is also doing things in harmony with your government and its people)

Artist (pseudonym) shared that freedom is essential and can only be achieved through unity.

"Ang Kalayaan ay mahalaga at makakamit lamang natin ito kung tayo ay nagkakaisa. Hindi ito trabaho ng isnag tao lamang kundi lahat ng taong nakatira sa isang pamayanan o bansa." (IDI-Res. No.004)

(Freedom is essential, and we can only attain it if we have unity. It is not just a work of one man but the work of everyone that belongs in a particular community or country.)

Happy (pseudonym) shared that to attain freedom we must endure some sacrifices like what the Jews did:

"Na realized ko na hindi madaling makuha ang freedom. Kailanagn nating magsakripisyo. Kung minsan parang gusto na nating sumuko, pero ang mga Jews hindi sumuko, sana gayahin natin sila." (IDI-Res. No. 007)

(I realized that freedom is not easily attained. We have to endure some sacrifices to attain it. Sometimes we feel like giving up, and we lose hope. But the Jews did not lose hope, so we should also go on like the Jews)

Sovereignty Issues - The third emerging theme is sovereignty issues. The participants shared their insights on what they had learned. Queen (pseudonym) voiced out her view about the sovereignty issue:

“Hanggang ngayon, walang pantay pantay sa akahit na anong bansa sa mundo. Akala lang natin meron pagkaka pantay pantay pero wala eh, may mga tao pa rin na ang taas ng tingin sa sarili. Siguro may sovereignty sa parte ng mga Germans pero hindi sa mga Jews. (FGD-Res.No.013)

(Until today, there is no equality in any country in the world. We just claim there is, but the truth is, there is no equality. There are still people who look at their selves with higher regard. There is maybe sovereignty on the part of the Germans but not to the Jews.)

Long Legs (Pseudonym) also expressed his realization and said:

"Dahil sa holocaust na realize ko na walang sovereignty sa ibang bansa. Nasa mayayaman lang ang kapangyarihan at ang posisyon. Walang Jew sovereignty sa Germany noon so walang equality." (IDI-Res. No. 006)

(Because of the holocaust I realized that sovereignty is not proper to all. The power is only in the hands of the rich, or those who are in position. The Jews were not sovereign when they were in Germany. So, there is no equality.)

Slender (pseudonym) also stated her sentiments regarding the sovereignty issue based on what they have read:

“Ang sovereignty ay para lang sa mayayaman. Wala pa rin talagang equality kahit sa ibang mga bansa." (FGD-Res.No.015)

(Sovereignty is only for the rich and powerful. Equality is not yet fully achieved even in other countries of the world) 
Escalante, L., \& Gomez, D.

Pouty also mentioned that the holocaust caused her to realize sovereignty issue:

"Dahil sa holocaust na realize ko na nag mga Jew ay non entity sa kanilang sariling bansa. Hindi sila kapantay ng mga Germans. Ang sovereignty ay nas mga makapangyarihan lamang katulad ng mga Nazi.” (IDI-Res.No.008)

"Because of holocaust, I realized that the Jews are no entity in their own country. They are not equal with the Germans. Sovereignty only belongs to those who are powerful like the Nazi." (Pouty)

The emerging themes were Fear to Fight, Feeling of Hatred to the oppressors, Bravery Leads to Survival, Admiration to Survivors of Holocaust, Condemnation of the Oppressors Acts, Extending Hands to the Needy, Holocaust is Far from Reality to Happen Again, Racial Discrimination, Image of a Hero, The Power of Action, The Essence of Freedom, Sovereignty Issue. These are the themes that were extracted from the responses of the respondents on the research questions that I prepared.

\section{Discussion}

This part indicates the reason why this phenomenological research was performed. The goal is to bring the subject to the forefront so that participants' thoughts and insights, as well as their encounters, can be taken in and fully understood. In addition, this untangles the qualitative methods around the logical accumulation of profound information and views through actual interviews and focus group discussion.

One of the darkest pages of European history is the holocaust. As a researcher, I felt responsible for sharing what transpired in my research for all humanity to discern and reflect. Furthermore, this study would like to emphasize and emphasize the significant role that Filipinos played during the holocaust. Even I, as the researcher, was not familiar or accustomed to the fact that Filipinos took part in helping and saving the victims and oppressed during the holocaust. No one can read the history of the holocaust and not be profoundly moved by the experience. It is shocking to be reminded of what human beings can do to other human beings. Perhaps we refer to the holocaust so often that we do it with too little thought. Perhaps we should force ourselves to re-read the horrors of an event in our recent history. An event so recent that we can still read the stories of the past that can describe the horrific event to us.

The holocaust, which is also called "Shoah," means destruction in Hebrew. The Hebrew word for destruction "is one of the greatest tragedies of modern human history" (Crowe, 1970). Seventy years later, Adult Americans contend that although the holocaust is a bleak but essential part of the history of the world, they only have very limited knowledge about it. That is why I was urged to choose this study. Integrating the holocaust into the classroom situation will be a great avenue to impart awareness that would somehow lead to the prevention of genocide. Among the many concerns of this study were raising awareness among Filipino learners, teaching them about the vital role Filipinos played during the holocaust, and emphasizing the essence and most accurate value of life.

The revealing perspectives of Filipino learners on the stories of the holocaust. The perspective shows regrets, sorrows, frustrations, and disappointments. It was also revealed that from the holocaust stories, the participants felt anguish, hatred, and rebellion towards the oppressor, as well as sympathy and sadness towards the oppressed during the holocaust. Nonetheless, a sense of hope and optimism emerges from the participants' candid perspectives. Life is what gives meaning to everything. If life were threatened, there would always be fear. From the responses of the participants, these were the themes that emerged: 4) Fear of fighting; 2) feeling of hatred towards the oppressors; 3) bravery leads to survival; 4) admiration for survivors of the holocaust; 5) condemnation of the oppressor's acts; and 6) extending hands to the needy.

After analyzing the participants' responses, I found out that one dominant idea that emerged was the fear to 
fight. The participants were disappointed because they looked up to the Europeans as brave people. They wanted the Jews to fight, and the death of millions of Jews frustrated them. But some participants justified the fear that the Jews felt. They thought the Jews wanted to fight, but they were overcome by fear.

We always value the essence of life because it is what makes our lives purposeful and meaningful. Without life, there is emptiness beyond comprehension. The participants' responses were evident in how they valued life, how they cared for life, and the fear of fighting because of the significance of life. We are all humans. We wanted to live life to the fullest. Survival is paramount, and it is an essential need. The participants believe that the Jews were driven to fight out of fear. Many lives were taken in front of their eyes. That made them weak, and they lost hope in living. Because of the loss of loved ones and family members during the Holocaust, the spirit of living was lost. Most Jews had given up on life. During the Holocaust, human rights and equality were clearly violated. Human rights are one optimistic influence affecting the current historical course of the world.

This is in line with the White Paper (2010) that human rights are a noble pursuit. It empowers people who are victims of injustice by carrying out their duties while receiving only a little protection. The advancement of universal rights tries to respect the inherent compassion of people regardless of peripheral attributes to show that democracy amends the disparate deal between the powerful and powerless. The discourse is empowering and potentially subversive. This tension between heightened awareness and the tenacity of the ancient order explains one of the challenges of twenty-first-century global society. Despite the pro-status-quo ideological doctrine, the Middle East, as the last bulwark of an archaic regime, is undergoing rapid change. Human rights are a sanguine force that influences modern-day history. The increasing tendency towards justice and freedom are creating a whirlwind of change, and North Korea is on the spot for its utterly disappointing human rights record.

Filipino learners acquired the feeling of hatred towards the oppressors. They saw Hitler as inhuman. They cannot contain the idea that a leader as ruthless as Hitler ever lived. Counting the deaths of millions, the participants revealed that their feelings towards Hitler would never change. What the Nazis did to the Jews was unforgivable. As stated by Miller (2016), laws that are not carried into effect, authorities without force and despised, property attacked, the safety of the individual violated, the morality of the people corrupted, no constitution, no government, no justice; these are the features of anarchy. This was evident during the holocaust and is even worse now. Filipino learners felt hatred as they felt there had to be something they could do to stop the monstrosity of the oppressors. The participants wanted to do something as they felt outraged and bursts of anger towards the Nazis. What occurred during the holocaust is categorically unacceptable and unforgivable. The feelings of hate and anger were natural for the participants to feel.

This is also connected to what Montero (2014) mentioned that the true nature of human rights was not obtained in the two most prominent views that have ever existed in the academe. It follows that the way sovereign political authorities always treat their people and places is the core of contemporary human rights practice constituted by a moral concept. Human beings are treated like mere instruments, with their intrinsic value and dignity being destabilized when leaders fail to fulfill the demands of a society with working human rights. Human rights practice in the international context is a historical breakthrough of their pre-existing morals.

In time, the Jews developed a mechanism to survive. Thus, the theme bravery leads to survival emerged. Eventually, as the picture of more deaths unfolded right before their very eyes, their fear turned into bravery. In their habitat, red and green bugs thrive. The birds like the taste of the red bugs, so they consume the red bugs. With the red bugs depleting, the green bugs are growing in number. Later, the red bugs will all be consumed, while the green bugs will be left thriving. This is an example of the survival of the fittest. "Survival of the fittest" is a phrase excerpted from Darwin's theory of evolution as a way of describing the system of natural selection. What happened during the holocaust led to the survival of those who had yet to realize their strength and that even in the darkest hour, there is always a light that shines.

In BBC Monitoring (2014), it has been written that throughout the world, people are concerned about human rights violations. The 1975 Helsinki Agreement guaranteeing basic human rights was signed by major powers 
in the East and West, but it is tough to monitor compliance with the treaty. Unfortunately, some small nations in the Baltic, Estonia, Latvia, and Lithuania, had no choice recently but to demonstrate against their oppressors. The brave people in Riga and Liepaja, born and have lived under a one-party system since 1939, took to the streets demanding their guaranteed human rights.

This is the holocaust, and there is nothing to be admired. However, the Jews being the victims, having shown courage and brevity as the genocide progressed, is admirable. The learners developed admiration for survivors of the Holocaust. The Jews were in their darkest hours, and some of them found their way out and knocked at our doors. They might be pitiful, but they fought the unknown, and then we found them. The survivors were genuinely unique. As a researcher, I cannot imagine myself if I had been in their shoes during the holocaust. I think I might not have survived at all. The participants have shown their sympathy and sincere gladness and admiration toward the Jews. Appreciation for the bravery and firmness of the Jews that, despite what they have been through, they have shown how valuable life is. The participants felt proud as Filipinos, knowing how great the Filipinos became a part of saving the lives of many during the holocaust under the presidency of Manuel L. Quezon. It is indeed an inspiring and heartwarming experience to know that our countrymen took part in helping the oppressed during the holocaust.

Stanziani (2013) focused on prohibiting Indians from migrating to Europe after being rescinded in 1916. But, it was only after the crafting of laws by the International Labor Organization, or ILO, that the treaty was realized or put into effect. Since the ILO, labor protection for workers has become evident, especially in transnational companies. However, labor conditions in smaller industries are still poor. It was only at the onset of the twentieth century that equality in labor rights applied to both giant and small industries was properly addressed. The participants likened Hitler to the devil. They took him as an evil person disguised as a human, and they tagged him as the worst leader in the history of humanity. After experiencing these emotions, participants naturally condemn the oppressors, resulting in another emerging theme: condemnation of the oppressors' actions. As previously stated, the Holocaust is inexcusable and unforgivable. Heartless, horrible, and evil were just a few of the descriptions mentioned by participants on the fifth emerging theme - condemnation of oppressors' actions. We cannot deny the fact that people will feel condemnation towards the oppressor's act. After all, what they did during the Holocaust was unimaginable and unforgivable. This theme emerges because most people, especially the participants, value and give significance to life. This only shows that our Filipino learners have sympathy and care towards life, and that they value the essence of life. The Filipino learners felt condemnation of the oppressors' acts because they are inhumane and violate the right to live of every human being.

In a statement, Murphy (2014) said that Mappens likened the thugs who exploited America's Prohibition, an experiment preventing the establishment of criminal empires among the great cities of America, to Tony Soprano. Most of these thugs were born between 1880 and 1905, all of whom were of foreign origin. Some of these men are Irish, but most of them are Italian or Jewish. The Irish men were ranked, but the Italians were the more popular ones. They were part of the mass immigration from Europe to America during the late twentieth century. As a result, this vicious act of Americanization, which these offenders successfully accomplished, was symbolic because they immersed themselves in society like underworld antagonists.

In a study conducted by Pruce (2010), a debate on universal human rights arose following the world's major wars. The monstrous killings perpetrated by the villains of the Second World War signaled the value of human rights. Not only were people shocked about the inhumane actions committed by the perpetrators of World War II at the concentration camps, but the bombings of Hiroshima and Nagasaki stood out as evidence of the strong probability that the existence of humans would be exterminated through self-annihilation. Science could not seem to serve its purpose simultaneously, and technology shifted its course, urging humanity to confront its darkest potential. Empirical questions such as "What is human?" and "What is history?" have become the subject of modern-day debate. "The human rights discourse was embedded in an existential aspect. We needed specific mechanisms to protect ourselves from self-aggression. " 
Despite knowing the consequences of helping the Jews, Filipinos still opened their doors to the Jews. This is just one of the responses that the participants have given. They also believed that rescuing the Jews who sought help from us made us admirable in some countries. Most of the participants saw Filipinos' helping hands as a history-changing gesture during the Jews' trying times, and thus the sixth theme emerged: extending hands to the needy. Filipinos are noted for being hospitable all over the world. Long before the holocaust, Filipinos had always been open and welcoming to others, which untowardly led to many colonization, such as the Spanish, the American, and the Japanese regimes. However, the Filipinos remained welcoming and heartwarming towards others. During the Holocaust, Filipinos assisted in welcoming Jews through our doors. Hill Jr. (2010) highlighted that those treaties had been designed to stabilize countries facing a human rights crisis. But, because of the correlation between these rights and the state's authority, some treaties fail to curb the oppressive behavior of the people in a society. Scholars should contemplate the possibility that "complying with human rights treaties depends on the kind of rights in question."

How do learners relate the stories to the social Issues at present? From the participants' point of view, the revealing perspectives that they had on the stories of the holocaust helped them relate these to the social issues at present. From the responses shared by the participants, there were three (3) themes that emerged. These were the following themes: 1) the holocaust is unlikely to reoccur; 2) racial discrimination; and 3) the image of a hero. The participants believed that the rise of information technology prevents event like the holocaust to occur and thus the theme holocaust is far to happen again emerged. That is how the participants see it. With the technological advancements, a suspicious action in one country will be easily detected. The participants also believe that the greatest breakthrough in preventing the holocaust from happening again is the universal declaration of human rights. They believed that through this policy, people created a bond to protect one another. Thus, the theme of the holocaust is far from reality and unlikely to happen again. We owe it all to history. Everything we had been through had been a lifelong lesson, and it was our way of mending broken pieces into one.

Also, Pruce (2011) noticed that human rights organizations positioned themselves as relevant actors in the emerging global civil society, with an expanding pool of affluent spectators from which to draw support. Recognizing human rights as a critical issue meant that a vast number of individuals might get invested and involved in the preservation of human dignity in a long-term way as part of a broader movement. Small-time or big-time discrimination is still discrimination. The participants believed that racial discrimination was present during the holocaust. Some of the participants think that racial discrimination is over. However, discrimination is still present even today. They perceive the cause of the holocaust as racial discrimination because Hitler hated the Jews. It was racial discrimination that sent six million Jews to the mass grave. It may be a common issue nowadays, but it is susceptible, and not all countries have successfully addressed it to date.

As mentioned by Olende (2018), racism undermines all struggles against oppression and thus weakens all those struggling, including white people. Discrimination has always been a major conflict all over the world. The past and the present still face this same monstrous conflict, which is racial discrimination. According to Malkina (2017), wages and salaries have the greatest and fastest-growing impact on inequality. The various forms of income revealed different paths of interregional disparity. Informal incomes made the second-largest contribution to overall inequality, but they were falling and negatively interacting with other widely distributed sources of income; as a result, they provided more than half of the total international union. Entrepreneurial earnings had a somewhat lower impact on inequality, mostly offset by their lower share of overall income. The most substantial soothing impact was shown in social transfers, although their contribution to convergence was exhausted. Property incomes had the most significant impact on inequality, especially during the recovery phase. In addition, informal wages served as substitutes for official incomes in Russia, creating self-replicating mechanisms for reducing inequality.

Stanziani (2013) stated, that in Britain and France, and in their colonies, employees and indentured immigrants have been virtually no longer disguised slaves (as literature of the 19th century has argued), but they 
had inferior prison popularity and some distance fewer rights than their masters. The Industrial Revolution in Britain was bolstered by the substitution of decreased prison constraints on hard work. In Britain and France, this trouble has been related to numerous factors. Over the lengthy-term --from the 16th to the early 20th centuries--the call for hard work rose due to territorial and colonial expansion, together with the boom of agriculture and trade, proto-commercial and later commercial development, regardless of demographic boom and slavery, which extended the need for a brutal work force.

The participants expressed how the image of a hero surfaced because of the brave acts committed by many people during the holocaust, especially the Filipinos. This is quite remarkable for the participants because they are aware of how inferior the Philippines is to giant economies, but they were able to extend a helping hand to the Jews. I believe that out of all the negativity, conflicts, and afflictions, a hero is born. We are all heroes. Whenever we lend a helping hand, we are heroes. We may fail, but in the end, our cape of hope flies and soars high. The emerging theme of the image of a hero can be gleaned from the perspective of the participants. Bowled (2019) the letter Further, Aristotle's famous definition of man as a political animal was that men are distinct from other animals by their ability to speak and by having the power of moral judgment. Aristotle saw the city-state as the ultimate natural form of civilized life and the best medium for realizing human potential.

Insights from Learners in the Stories Read. The insights from the stories that the readers learned were revealed in the following three (3) themes that emerged. The will to fight is what made the Jews survive the tragic holocaust. The fight for survival is the power of action of many Jews during this trying time of the holocaust. The tragic past would always be an unforgettable experience for Jews, and that this made them acquire the power of action, the strength of will to live and fight for their lives. The power of action is the most crucial step in achieving success. The simple truth is that dreams, visions, and goals are achieved and accomplished through the power of action. Without definite action, no one can achieve a positive goal. The power of action reveals one's potential in life. This is consistent with Pruce (2011)'s assertion that through citizen engagement in global affairs, people foster a collaborative response to crisis based on compassion and morality. As a result, the possibility of solidarity grows where borders do not matter, and the welfare of human rights is a universal concern. However, when human rights participation is facilitated by popular culture mechanisms, these tendencies are not translated into meaningful political action. This passion produces energy that could flare up crisis, outrage, and grief, and then the audience becomes deflated and detached.

Freedom is what makes us superior among other living things on earth, apart from our language. Freedom is something the participants valued, for them the essence of freedom is ultimate. The phrases uttered by the participants included: democratic country, peace, and dignity, free from oppression and abuse. It was also revealed from the participants' insights that the sustainability of freedom is responsibility and commitment. Living in harmony with others was also evident from the participants' insights based on holocaust stories. Also, freedom means equality for every person. After all, if we want to be free and live in a peaceful community, we must keep peace and harmony. The essence of freedom, according to Rob McCoy, as reported by Geibler and Markel (2016), is the proper limitation of government. When the government is large, citizens have fewer chances of being scrutinized by the authorities. So, a government should be manageable and within the range of the leader's capacity. Monarchy, on the other hand, is a different thing. Everyone is destined to serve the King, so clamoring for freedom is a mockery. However, a debate on universal human rights came up after the major wars of the world. The monstrous killings perpetrated by the villains of the Second World War signaled the value of human rights. Not only were people shocked about the inhumane actions committed by the perpetrators of World War II at the concentration camps, but the bombings of Hiroshima and Nagasaki stood out as evidence of the strong probability that the existence of humans would be exterminated through self-annihilation. Science could not seem to serve its purpose simultaneously, and technology shifted its course, urging humanity to confront its darkest potential. Empirical questions such as "What is human?" and "What is history?" have become the subject of modern-day debate. "The human rights discourse was embedded in an existential aspect. We needed specific mechanisms to protect ourselves from self-aggression "(Pruce, 2010). 
During the holocaust, only the Germans were sovereign citizens of their country. Although many Germanys' population are Jews, the participants believed that the Jews were never an integral part of Germany. While sovereignty should have been a power that every citizen held, the Jews were powerless. The presence of sovereignty issues was evident. They were considered second-class citizens in their own country and therefore could only do-little things as citizens. Thus, the participants concluded that sovereignty did not exist during the time of the holocaust. Sovereignty has always been political in concept (Volk, 2013). The two world wars and the French Revolution have made it even more identified as a political idea inside and outside force. Then there was popular sovereignty as the law, legal sovereignty as the parliament, and parliamentary sovereignty as the state. However, a lot of contributing factors change this concept. Because of these changes, the sovereignty of states is in question. However, with all these sovereignty concepts emerging, defining the function, and meaning of sovereignty is underway.

The concept of state sovereignty is that states have total and exclusive power over all people and things inside their borders. It also encompasses the notion that all states are equal. In other words, all states have the same right to act as a state and make decisions about what happens within their borders, regardless of their acreage, masses, population sizes, or financial resources. There is not any equality, and there is not any liberty. Filipinos' role during the Holocaust only demonstrated a readiness to intercede on behalf of others, a willingness to engage in civil disobedience, empathy for others' suffering, and tolerance of individuals with different values and beliefs in life. Volks (2019) wrote that the concept of sovereignty is not political, but it holds a special status. It is a foundational concept, a worldview-conceiving political concept. Indeed, there have been philosophers and political thinkers of the preceding time and now who have approximately opted for sovereignty, or who have defined political activities and stories as status in a specific frontline role for sovereignty-centeredness. Hannah Arendt's paintings are widely known, and one of the most notable examples is her portrayal of the American revolution and founding records as decidedly anti-sovereign. However, in political and prison thinking, they are no longer capable of success because they have provided an adequate opportunity for bonding capacity.

This study promotes critical thinking about knowledge relevant to trauma and resilience. Sovereignty and survivorship provide participants' perspectives based on the stories of the holocaust. This study also provides awareness of genocide and attitudes towards diversity and discrimination. Studying the holocaust conveys civic value, injustice, tolerance, and the importance of democratic liberties. According to Russell (2005), teaching about the Holocaust increases student knowledge of the importance of plurality and increases diversity tolerance in pluralistic societies. This can be done both inside and outside of the classroom, for example, by visiting a holocaust museum or memorial site. This study on Filipino learners' perceptions of Holocaust survivors will aid future researchers in demonstrating personal growth, family functioning, and community support under pressure. This study will also serve as an opportunity for the creative exchange of trends, innovations, and problems relevant to the social work education of future researchers. A child of the holocaust would need to grapple, cope, and fight with complicated moral issues. A rationale for mandating holocaust education as a way of dealing with the increase in hate crimes is that the survivors of the holocaust continue to advance, and the world is looking for ways to tell the stories of the holocaust.

\subsection{Implications for Teaching Practice}

The inference that has been drawn from the results shows the importance of social equality, the significance of power and authority, the feeling of need to survive and the preservation of life. There are many things that urge humanity to do the things they do. We feel hatred and anger when we are oppressed and hurt. The culture suggests seeking importance through power and authority. Social equality would imply that equality is first and foremost about people's relationships and interactions with one another, rather than being primarily about distribution. As mentioned by John Rawls, he further suggests its connection to Marxism with the theory of social justice. He used the social contract theory to generate principles of justice for assigning basic rights and duties and determining the division of social benefits in society. From the study results, it can be gleaned that the Filipino learner's perception values equality and human rights. Many philosophers have written about the 
importance and relevance of social equality.

It played an essential role in real-life egalitarian movements such as feminism and the civil rights movement. The findings are also linked to Bradley Jr.'s (2018) concept of socialism, which claims that it entails a community that rejects class divisions, believes in equality, common ownership, socialization of the means of production, and equal opportunity for personal growth for all. The study's findings also reveal a significant concern for everyone's well-being, particularly those who were oppressed during the Holocaust. It can be concluded that there has been neglect and that the majority of people are unaware of what it is and why it might be valuable. As an implication for education, the revealing perspectives of the learners on the stories of the holocaust are inclusive of bravery, hatred towards the oppressors, admiration for survivors of the holocaust, condemnation of the oppressors' acts, and willingness to help the needy, and these discoveries can be a motivation for teachers to continue their quest in providing quality education with the use of awakening the interest of learners towards the occurrences in the past that they may not have known about before.

On the other hand, how learners relate to the stories of the holocaust to the social issues at present reflects their realization that the holocaust is far from reality to happen again, racial discrimination is present, and the image of a hero may surface during times of difficulty. This is particularly important since it will be a basis for the teachers on a certain level that the students understand and compare what happened in the past and what is happening in the present time and what impact it might have on their lives. Aside from that, the insights of the learners in the stories they have read have made them comprehend the power of action, the essence of freedom, and sovereignty issues during the holocaust. Furthermore, the students, particularly those who took part in this study, discussed their experiences and concerns concerning the illuminating perspectives in reference to current societal issues as well as their thoughts on Holocaust stories. Reflecting on what they have shared, DepEd officials need to ensure that the needs of the teachers, master teachers, and principals are provided to ensure that their provision of quality education is maximized. This should also motivate them to review, monitor, evaluate, and re-evaluate the continual delivery of literature-related instructions to ensure that students are receiving accurate knowledge about what happened in the past.

Additionally, for the school, they continue to acknowledge, appreciate and contribute to fighting inequality through their support of the school's project that tackles discrimination, with an emphasis on women's rights. Promote in-depth preservation of the history, which includes the history of holocaust where Filipinos has played an important role. For the teachers, to continually impart in teaching for the awareness of every Filipino student that inequality pushes people to move or migrate. To always inculcate appreciation among learners the significant role that Filipinos portrayed during the holocaust. Because this study was conducted during the pandemic, when schools used distance learning, parents were more involved in the learning process. This is one great opportunity for module writers like me to start educating people about the holocaust by including articles about it in the lessons in English and Araling Panlipunan. Since parents are assisting their children, they will also have the chance to read these articles and be enlightened about the subject. The mere fact that the Division Office allows this study to be conducted is already an outstanding contribution to the academe because it serves as an introduction to learning another phase of history. With awareness being attained, involvement comes next.

Also, for the learners to have a constant appreciation for history and the value of life. To have a greater understanding of what social equality and human rights really mean, to enjoy freedom, and to be non-discriminatory. To exhibit unwavering support for social equality and human rights in the community, as well as to take initiatives to increase life satisfaction. Enact and enforce legislation and adopt adequately resourced national multi-sectoral plans of action and programs to end social inequality and human rights violations. Promote equality and exercise human rights as everyone is entitled to the right to live. Lastly, priority must be placed on ending social inequality. Beyond the harm and injustice caused to individuals and communities, inequalities stall progress, reduce economic efficiency, hinder growth, threaten social cohesion and stability. We must step -up and address social equality for the well- being of children, our youth, and families. 


\subsection{Implications for Further Research}

The researcher urges some specific actions to be taken. Some specific suggestions are made about further research on the topic. Inequality should be addressed in its broadest sense. Today, billions of people face appalling inequities in terms of chances, choices, resources, security, freedom, and power. They face social, economic, and political marginalization, and they are also subjected to violence and discrimination because of damaged social and gendered norms.

This study is limited only to the 20 Grade 11 students of Pipisan Maug National High School in Tagum City Division; the following implications for future research are developed:

$>\quad$ Since the findings of this specific study were limited only to the lived experiences of the 20 grade 11 students from a secondary school in relation to the revealing perspectives on the stories of the holocaust, how they relate the stories to the social issues at present, and their insights and perceptions with regards to the stories they have read, future research may be conducted investigating the revealing perspectives of students from other high schools relating to the stories of the holocaust.

$>\quad$ Aside from that, because the participants in this study are all from the same public high school, future researchers who share my interest in exploring the revealing perspectives in relation to holocaust stories may choose to conduct a similar study on private secondary schools.

$>$ Moreover, future researchers also have the liberty to conduct a parallel study to investigate this phenomenon among students from the tertiary level with the subject literature.

$>\quad$ In addition, future researchers interested in conducting the same inquiry may also opt to conduct it in quantitative method to have a more significant number of respondents and to beseech the use of statistical tests to conclude with findings that are generalizable in all situations.

\section{Concluding Remarks}

The research on "Stories of Holocaust from the Optic of Filipino Learners" highlighted the necessity and significance of the study. The findings were carefully validated, as trustworthiness is pertinent in the conduct of any qualitative phenomenological research. To sum it up, results of the study show that students have various revealing perspectives when it comes to the stories of holocaust and these students needed support from parents, teachers, and the school for them to be able to be guided in their insights to what happened in the past especially that they can relate the events that happened before to the social issues at present. Outcomes also confirm that even though the holocaust has brought much of negative impact on the world, there are still positive outcomes that can be seen from the said historical event.

\section{References}

Ahmed, H. (2016). Factors impeding economic growth in sub-Saharan Africa despite liberalized trade policies: Perceptions of academic experts (Order No. 10254183). Available from ProQuest Central.

Al-Jufairi, K. (2015). The centrality of middle class: Sociopolitical resilience \& economic stability (Order No. 10305685).

Acharya, R. (2017). Bhattarai says he has not renounced method. Journal of Phenomenological psychology, 43(1), 3-12.

BBC Monitoring Central Asia UN initiative 'inspired' by south Korea. The Jakarta Post (2007, Sep 21).

Bhat, S. A. (2019). The Kashmir conflict and human rights. Race \& Class, 61(1).

Bloom \& Crabtree (2006) The qualitative research interview. Medical Education, 40, 314-321. https://doi.org/10.1111/j.1365-2929.2006.02418.x

Boddy, C. (2005). A rose by any other name may smell as sweet but "group discussion" is not another name for a 
"focus group" nor should it be. Qualitative Market Research, 8(3), 248-255.

Boot, M. (2012). The aim of a theory of justice. Ethical Theory and Moral Practice, 15(1), 7-21.

Borchert, S. D. (2008). Class counts: Education, inequality, and the shrinking middle class. Choice, 45(7), 1248.

Bradley, R. L., J.R., \& Donway, R. (2010). Capitalism, socialism, and "the middle way" A taxonomy. The Independent Review, 15(1), 71-87.

Bricki, N., \& Green, J. (2007). A guide to using qualitative research methodology. Medecins Sans Frontiers.

Campbell, R. (2012). Evaluating meta ethnography: systematic analysis and synthesis of qualitative research. NIHR Health Technology Assessment Program.

Cataldi, S. (2018). A proposal for the analysis of the relational dimension in the interview techniques: A pilot study on in-depth interviews and focus groups. Quality and Quantity, 52(1), 295-312.

Chin, M. K. (2014). Political ideologies of upper echelons: Implications for top executives' pay arrangements (Order No. 3647427). Available from ProQuest Central. (1639034511).

Cope, Diane G, (2014). Methods and meanings: Credibility and trustworthiness of qualitative research. Oncology Nursing Forum, 41(1), 89-91.

Corbin, J., \& Strauss, A. (2008). Basics of qualitative research: Techniques and procedures for developing grounded theory (3rd ed.). Sage Publications, Inc.

Cowan, P., \& Maitles, H. (2017) Understanding and Teaching Holocaust Education. https://doi.org/10.4135/9781473984028

Creswell, J.W. (2007). Qualitative inquiry and research design: Choosing among five approaches (2nd ed.). Thousand Oaks, CA: Sage.

Creswell, J., \& Miller, D., Woodsong, S. (2011). Theory into practice college of education, The Ohio State University, Ohio, USA.

Creswell, J. (2013). Qualitative inquiry and research design: Choosing among five approaches ( $3^{\text {rd }}$ ed.). Thousand Oaks, CA: Sage.

Creswell, J. (2014). Research Design: Qualitative, Quantitative, and Mixed Methods Approaches. (4 ${ }^{\text {th }}$ Ed.). SAGE Publications, Inc. California, USA.

Creswell J. W., \& Miller, D. (2000). Determining validity in qualitative inquiry. Theory into practice, 39(3), 124-130. SAGE Publications Inc., California, USA.

Creswell, J. W., \& Brown, M.L. (1992 Fall). How chairpersons enhance faculty research: A grounded theory study. The review of higher education, 16(1), 41-62.

Davis, S. H. (2007). Bridging the Gap between Research and Practice: What's Good, What's Bad, and How Can One Be Sure? Phi Delta Kappan, 88(8), 569-578. https://doi.org/10.1177/003172170708800804

De Moortel, D., Vandenheede, H., Muntaner, C., \& Vanroelen, C. (2014). Structural and intermediary determinants of social inequalities in the mental well-being of european workers: A relational approach. BMC Public Health, 14, 938.

Economic gangsters: Corruption, violence, and the poverty of nations. (2008). Ethics \& International Affairs, 22(4), 438-439.

Editorial Projects in Education Research Center. (2011, July 7). Issues (2012, Oct 18). BBC Monitoring Middle East

Edward, F. A. (2008). The fight against corruption and its implications for development in developing and transition economies. Journal of Money Laundering Control, 11(1), 76-87.

Egyptian muslim brotherhood leader criticizes "oppressive" arab leaders. (2006, Aug 21). BBC Monitoring Middle East

Elias, M. J., White, G., \& Stepney, C. (2014). Surmounting the Challenges of Improving Academic Performance: Closing the Achievement Gap through Social-Emotional and Character Development. Journal of Urban Learning, Teaching, and Research, 10, 14-24.

Erameh, E. (2017) Humanitarian intervention, Syria and the politics of human rights protection, The International Journal of Human Rights, 21(5), 517-530.

Fagan, A. (2017) Human Rights and Cultural Diversity: Core Issues and Cases. Edinburgh University Press, Ltd. Finn, D. (2006, 03). Sustaining equality and justice in the struggle for Socialism. Monthly Review, 57, 52-62. 
https://doi.org/10.14452/MR-057-10-2006-03_5

French president officially admits his country oppressed algerians. (2012, Oct 18). BBC Monitoring Middle East

Fuchs, Christian. 2012. New Marxian Times. Reflections on the 4th ICTs and Society Conference "Critique, Democracy and Philosophy in 21st Century Information Society. Towards Critical Theories of Social Media”. Triple C - Open Access Journal for a Global Sustainable Information Society, 10(1): 114-12.

Gatens \& Johnson. Holocaust, Genocide and Human Rights Education: Learning Political Competencies for 21st Century Citizenship. Facing History and Ourselves, 1(2).

German president warns of dangers to democracy. (2017, Jan 18 PrensaLatina

Giebler, H., \& Merkel, W. (2016). Freedom and equality in democracies: Is there a trade-off? International Political Science Review / Revue Internationale de Science Politique, 37(5), 594-605.

Giorgi, A. (2012). The descriptive phenomenological psychological Khalid Jamil Rawat. Phenomenological Research Method.

Gorbachev raises hope of oppressed countries. (1987, Dec 16). Toronto Star.

Hancock, A. (1998). Overview: Social classes in America today Communities, (98), 31.

Hendi, Y. P. (2016). Sight beyond sight. Journal of Financial/ Crime, 23.

History.com, 2009. Fidel Castro https://www.history.com/topics/cold-war/fidel-castro

Hodges, K. E., \& Sulmasy, D. P. (2013). Moral status, justice, and the common morality: Challenges for the principlist account of moral change. Kennedy Institute of Ethics Journal, 23(3), 275-96.

Ian Traynor, i. K. (2005, Apr 04). Death of the pope: Leader, reformer

InSites (2007). Analysis of qualitative data for beginners. www. academia. edu.

Kohli, R. (2012) Racial Pedagogy of the Oppressed: Critical Interracial Dialogue for Teachers of Color, Equity \& Excellence in Education, 45, 181-196.

Krueger, A. B. (2017). Where have all the workers gone? An inquiry into the decline of the U.S. labor force participation rate. Brookings Papers on Economic Activity, 1-87.

Kvale, S. and Brickman, S. (2009). Interviews (2nd edition) : Learning the craft of qualitative research interviewing. Thousand Oaks, CA: Sage Publication.

Laverty, S. M. (2003). Hermeneutic phenomenology and phenomenology: A comparison of historical and methodological considerations. International Journal of Qualitative Methods, 2(3).

Malkina, M. (2017). Contribution of various income sources to interregional inequality of the per capita income in the russian federation. Equilibrium, 12(3),399-416.

Marxism inspired deep changes in china, says xi jinping. (2018, May 04). Prensa Latina.

Meisenhelder, T. (2001). The contemporary significance of karl korsch's marxism.Nature, Society, and Thought, 14(3), 325.

Miller, R. (1974). Rawls and Marxism. Philosophy \& Public Affairs, 3(2), 167-191. Retrieved April 26, 2021, from http://www.jstor.org/stable/2264905

Mkandawire, T. (2014). The spread of economic doctrines and policymaking in postcolonial africa. African Studies Review, 57(1), 171-198.

Morlino, L., Dressel, B., \& Pelizzo, R. (2011). The Quality of democracy in Asia-Pacific: issues and findings. International Political Science Review, 32(5),

491-511. https://doi.org/10.1177/0192512111418334

Morris, M. (2011). Curriculum and the holocaust competing sites of memory and representation. New Jersey: Lawrence Erlbaum Associates.

Moustakas, C., \& Grempes, V. (2014). Phenomenological research method, Thousand Oaks, CA. Sage.

Muntaner, C., Ng, E., Chung, H., \& Prins, S. J. (2015). Two decades of neo-marxist class analysis and health inequalities: A critical reconstruction. Social Theory \& Health.

Murphy, D. P. (2014). Prohibition gangsters: The rise and fall of a bad generation. The Journal of American Culture, 37(2), 242-243.

Musvoto C, Nortje K, De Wet B, Mahumani BK, Nahman A. Imperatives for an agricultural green economy in South Africa. S Afr J Sci.,111(1/2). https://doi.org/10.17159/sajs.2015/20140026

Myanmar rejects US allegations about muslims being oppressed in country: BJP MLA ghanshyam tiwari 
Escalante, L., \& Gomez, D.

jaipur]. The Times of India

Nandi, P. (2017, Jun 08). Rajasthan farmers most oppressed Jun 08, 2017, 18:43.

Neilson, D. (2018). In-itself for-itself: Towards second-generation neo-Marxist Class theory. Capital \&Class

Olende, K. (2018) Marxism and anti-racism, Critical and Radical Social Work, 6(2), 159-77, https://doi.org/10.1332/204986018X15321002854920

Oliveira, F. (2019) The rise of the Latin American far-right explained: dependency theory meets uneven and combined development, Globalizations, 16:7, 1145-1164.

Owen, D.A. The Impact of Economic Development on Political Interest Across Social Classes in China: Turning the Chinese Dream into a Chinese Reality? J OF CHIN POLIT SCI 20, 185-202 (2015). https://doi.org/10.1007/s11366-015-9345-3

Pandiella, A. G., \& Gabriel, M. (2017). Deconstructing income inequality in costa Rica: AN INCOME SOURCE DECOMPOSITION APPROACH. Paris: Organization for Economic Cooperation and Development (OECD).

Park, M. (2015) How the Philippines saved 1,200 Jews during the Holocaust. CNN Updated 2051 GMT (0451

HKT) February 3, 2015

https://edition.cnn.com/2015/02/02/world/asia/philippines-jews-wwii/index.html

Parkinson, D. (2014, Jul 16). A million more jobs, a work force in worse 23(2), 289-316. https://doi.org/10.1108/JFC-12-2014-0063

Piacentini, L., \& Katz, E. (2017). Carceral framing of human rights in Russian prisons. Punishment \& Society, 19(2), 221239.

Pins, D. (2014, Dec 23). A Christmas story of Philippine charity repaid; when Jews needed to flee the holocaust, they found a haven in the Philippines. Wall Street Journal (Online)

Polifroni, E \& welch M. (1999) Perspectives on Philosophy of Science in Nursing.

Pressman, S. (2007). The decline of the middle class: An international perspective. Journal of Economic Issues, 41(1), 181-200. Political landscape. International New York Times

Pruce, J. R. (2011). Global human rights in an age of consumerism (Order No. 3491151). Available from ProQuest Central. (919002975).

Raagas, E.L. (2010). Understanding research basic concepts (with computer lapproaches to basic data analysis), Iwag Printing Publication, Cagayan de Oro, Philippines.

Richards, L. and Morse, J. (2007). User's guide to qualitative methods, Thousand Oaks, CA: Sage.

Roschanack Shaery-Yazdi (2020) The Cause of the Lebanese Disappeared in Syria: Human Rights, Social Movements and Politics in Lebanon, Middle East Critique, 29:2, 159-175.

Rubin, A. J. (2015, Dec 08). National front victory in france shakes up (2015, Dec 22).

Sampling in research. (2012). In Suter, W. N. Introduction to educational research: A critical thinking approach (pp. 217-249). Thousand Oaks, CA: SAGE Publications.

Silverman, D., \& Green, T. (2010). Doing qualitative research: a practical handbook. SAGE Publication.

Shırıyev, Z , Davies, C . (2013). The Turkey-Armenia-Azerbaijan Triangle: The Unexpected Outcomes of the Zurich Protocols. PERCEPTIONS: Journal of International Affairs, 18(1), 185-221.

Soares, et al. (2013) Marxism as a threshold and Methodological Framework in Collective Health Implications for Systematic Review and Synthesis of Evidences.

Speziale, H.J.S. \& Carpenter, D.R. (2007). Qualitative research in nursing: advancing the humanistic imperative (4th edition). Philadelphia: Lippincott Williams and Wilkins.

Solo, R. (1978). The neo-marxist theory of the state. Journal of Economic Issues (Pre-1986), 12(000004), 829.

Stanziani, A. (2013). Local bondage in global economies: Servants, wage earners, and indentured migrants in nineteenth-century france, great britain, and the mascarene islands. Modern Asian Studies, 47(4), 1218-1251.

Sloan, A., \& Bowe, B. (2014). Phenomenology and hermeneutic phenomenology: The philosophy, the methodologies, and using hermeneutic phenomenology to investigate lecturers' experiences of curriculum design. Quality and Quantity, 48(3), 1291-1303.

Stephen J.,Jr. (2005, Jul). The soul of socialism: Connecting with the people's values. Monthly Review, 57,

234 Consortia Academia Publishing (A partner of Network of Professional Researchers and Educators) 
114-125.

Support to oppressed countries Iran's major policy priority - senior MP. (2015, Dec 22). BBC Monitoring Central Asia Retrieved from 9

Suter, W. N. (2012). Qualitative data, analysis, and design. In Introduction to educational research: A critical thinking approach (pp. 342-386). SAGE Publications, Inc.

Tanner, D. (2006, 04). What's hot? D2D, data reduction, data classification. InfoStor, 10, 40-41.

Thomas, P. (1986). Political Theory, 14(4), 672-675.

Volk C. The Problem of Sovereignty in Globalized Times. Law, Culture and the Humanities. February 2019. https://doi.org/10.1177/1743872119828010

Westhoff, K. (2014). The decision-oriented interview (DOI) as an in-depth selection interview. Psychological Test and Assessment Modeling, 56(2), 137-153.

White Paper on North Korean Human Rights 2010 Seoul: Database Center for North Korean Human Rights-North Korean Human Rights Archives.

Whiting, L. S. (2008). Semi-structured interviews: Guidance for novice researchers. Nursing Standard (through 2013), 22(23), 35-40.

Willis, J.W. (2007). Foundations of qualitative research: interpretative and critical approaches. Sage Publications, Inc: New edition

Wilson, A. D., Onwuegbuzie, A. J., \& Manning, L. P. (2016). Using paired depth interviews to collect qualitative data. The Qualitative Report, 21(9), 1549-1573. 
Escalante, L., \& Gomez, D.

236 Consortia Academia Publishing (A partner of Network of Professional Researchers and Educators) 